This article has been scanned by iThenticat No plagiarism detected

Volume 3, Issue 6, December 2021

p.41-61

\title{
PRACTINCING DEGREE OF FIRST CYCLE HEAD MASTRES IN NORTH AL BATINAH GOVERNORATE IN SALTANATE OF OMAN OF THEIR ROLES IN ACTIVATING PARTNERSHIP BETWEEN SCHOOL AND FAMILY
}

http://dx.doi.org/10.47832/2757-5403.6-3.4

\section{Mohammed SALEH ALAJMI ${ }^{1}$ \& Fatema Ali Salim ALMAQBALI2}

\begin{abstract}
:
The target of this study is to identify the degree to which school principals in the first cycle of the North Al Batinah governorate in Sultanate of Oman practiced their roles in implementing the partnership between the school and student families, and whether there were statistically significant differences between the averages of the chosen sample participants in this subject in Oman and weather if there is a major role played by the amount of experience of each individual. The study sample consisted of 244 female teachers from the first field in the North Al Batinah governorate in Oman, who constituted $17.2 \%$ from the total 1422 female teachers. A questionnaire consisting of 30 items was used, divided into 3 sections (cultural field, educational field, and the social field). In order to ensure the validity and reliability of the tool, it was applied to 30 teachers outside the sample under study, as the percentage of stability was according to the Cronbach Alpha coefficient .976 At the end and after analyzing the data, the partnership between the school and the family showed a high degree of partnership commitment, with an average of 4.19. The results indicated statistically there was no significant differences between the averages of the sample members for the degree of participation of school principals in North Al Batinah in Sultanate of Oman partnership between the school and the family which was due to the years of experience of the individuals. The study recommended the necessity of adopting a program to exchange visits between the principals of the first cycle schools and their counterparts in the rest of the educational governorates in order to benefit from their high experience in activating the partnership between the school and the students families, it also

\footnotetext{
${ }^{1}$ Dr. , Suhar University, Sultanate of Oman, majmi3@su.edu.om, https://orcid.org/0000-0002-6882-7608

${ }^{2}$ Researcher, The Ministry of Education, Sultanate of Oman, F163316@moe.om, https://orcid.org/0000-0003$\underline{2163-4670}$
}

Copyright (C) Published by IJHER Journal, www.ijherjournal.com Rimar Academy, Fatih, Istanbul, 34093 Turkey

All rights reserved 
recommended that the media should play a role in broadcasting and publishing some programs that enhances the culture of partnership between the school and the families, and to also include a special field for activating the partnership between the school and the family in the school's annual plan and programs. In addition, it also recommended creating an electronic educational platforms for students to help the guardian to follow up on all what is presented to the student, so that the principals are able to face and keep pace with any upcoming new challenges .

Key words: First Cycle, Principals, School, Family, North Al Batinah, Sultanate of Oman.

\section{درجة ممارسة مديرات مدارس الحلقة الأولى بمحافظة شمال الباطنة في سلطنة عمان أدوارهن في تفعيل الثراكة مدارين بين المدرسة والفئة والأسرة}

فحمد بن صالح بن محمد العجمي 3

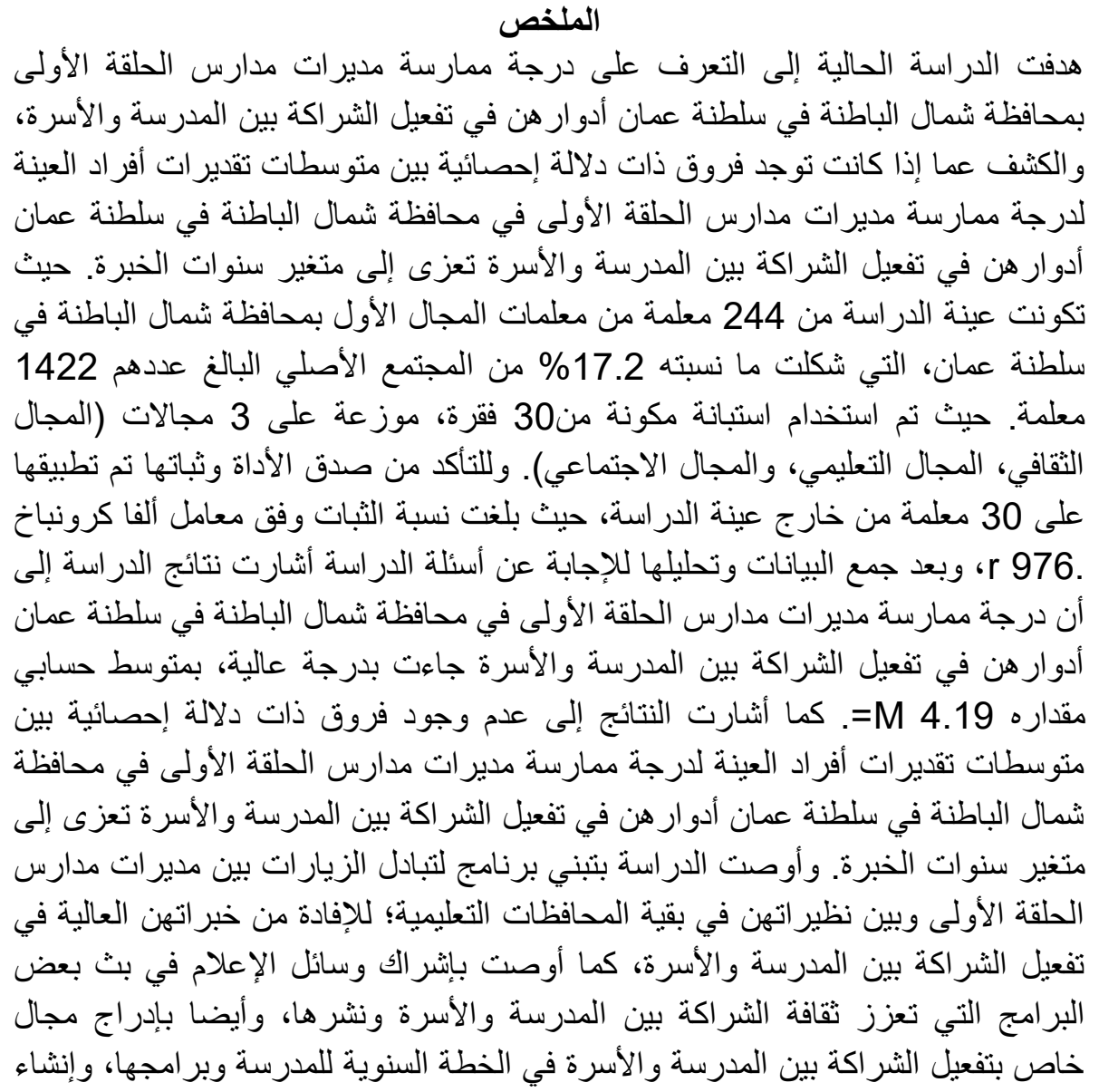




\begin{abstract}
منصات تعليمية إلكترونية للطلبة؛ لمساعدة ولي الأمر على متابعة كل ما ينم تقديمه

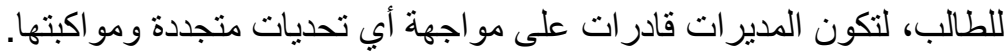
الكلمات المفتاحية: الحلقة الأولى، الثر اكة، المدرسة، الأسرة، شمال الباطنة، سلطنة عمانه
\end{abstract}

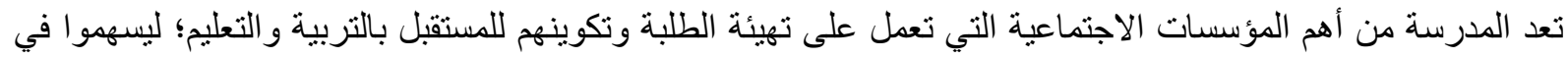

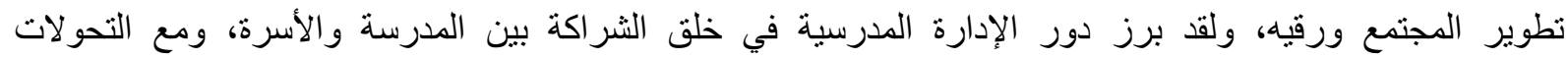

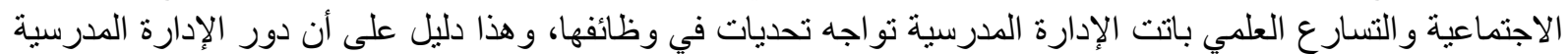

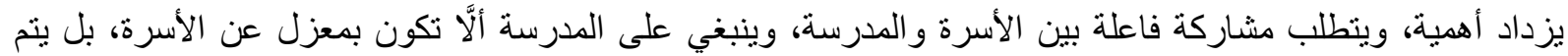

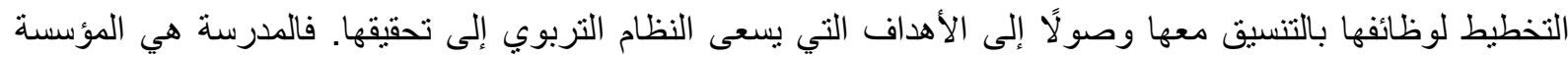

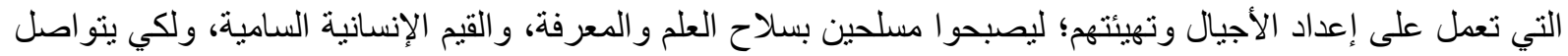

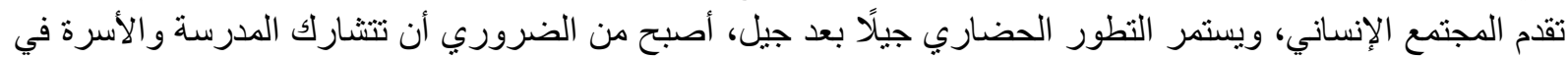

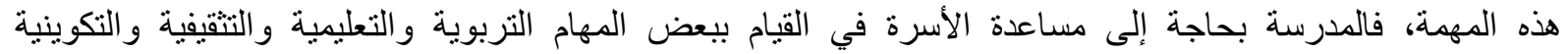

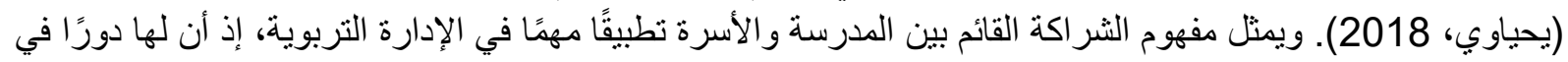
معالجة الكثير من القضايا التربوية والتعليمية. فالعملية التربوية في جملتها عملية تفاعلية لأعضاء تربطهم رابطة رابطة متينة

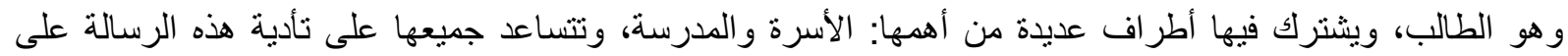

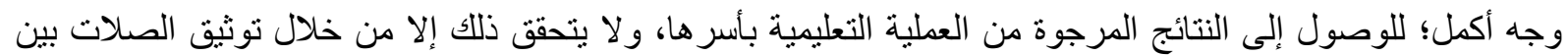

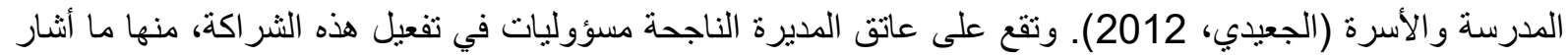

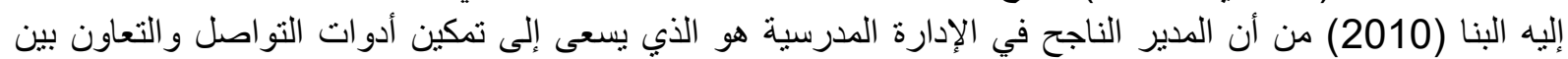

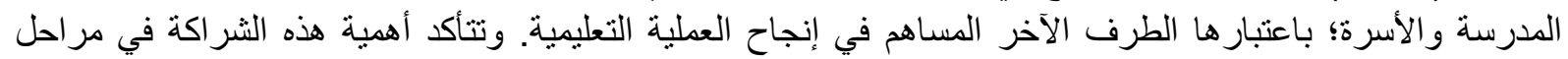

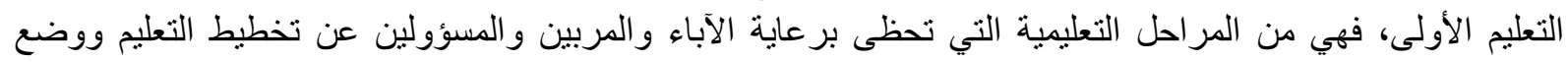

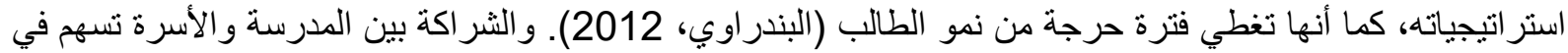

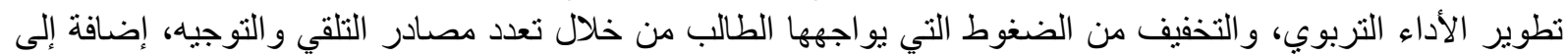

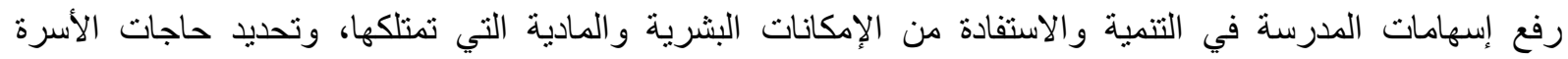

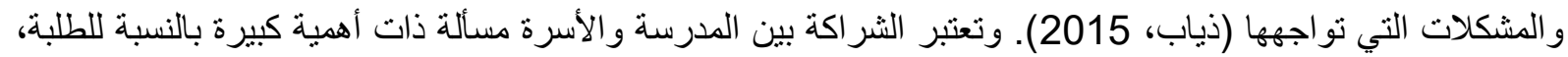

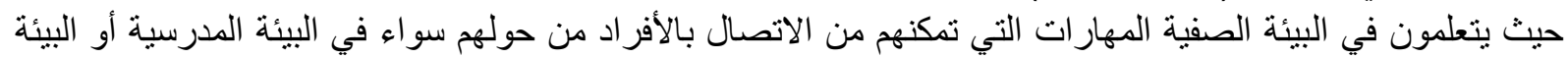

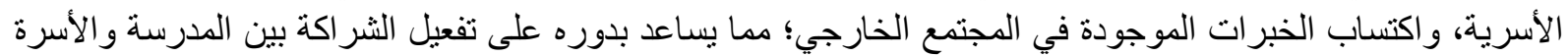

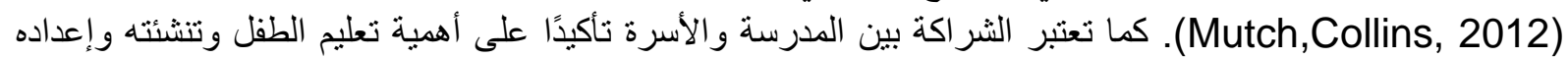

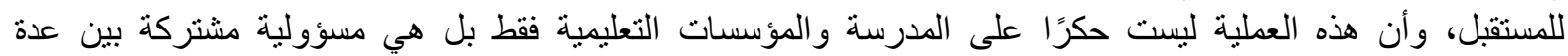

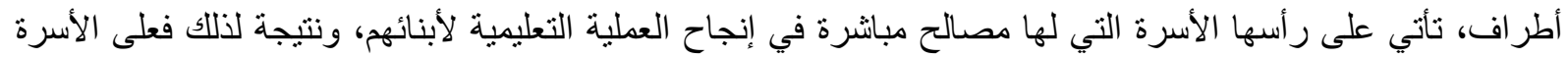

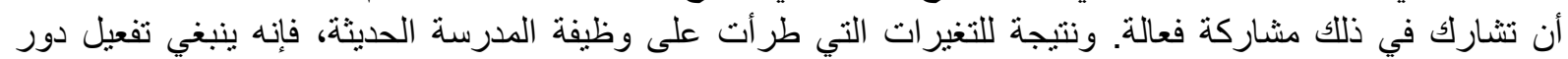

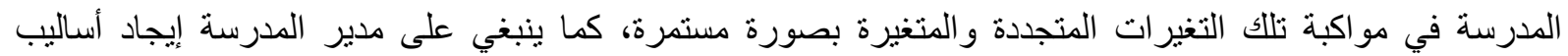

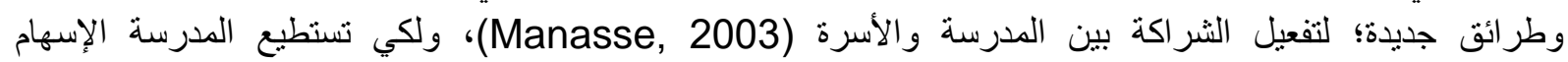

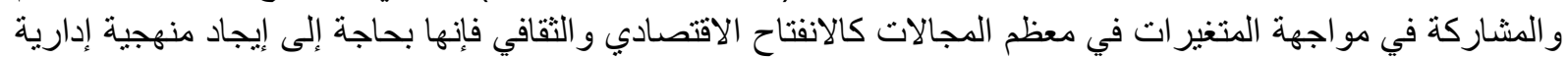

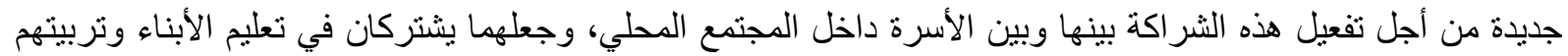

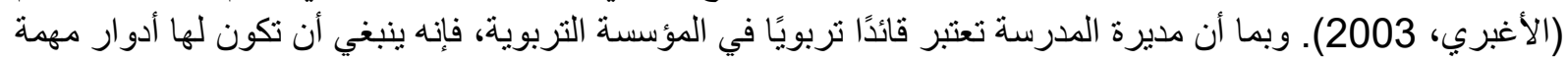

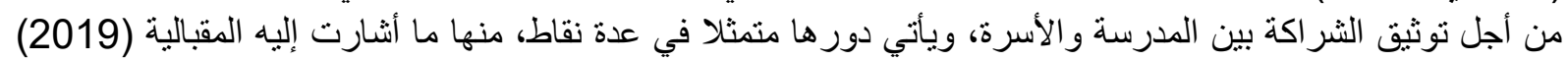

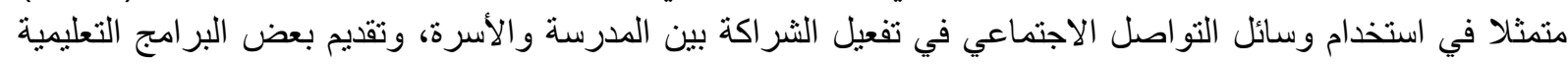

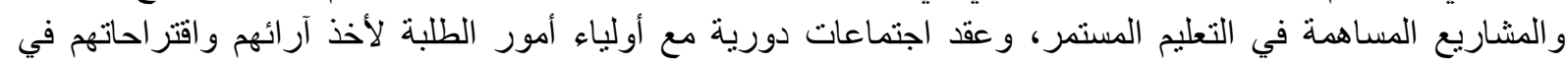

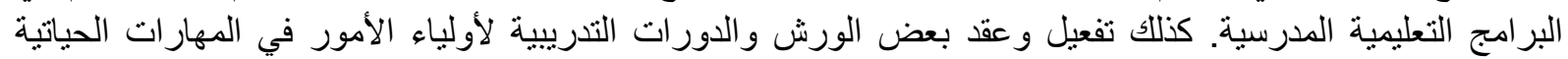

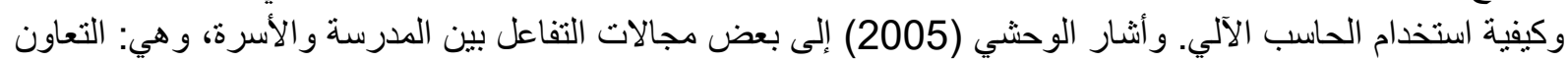

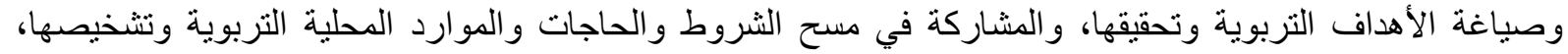
و المشاركة في عملية التعليم والتعلم. وذكر عابدين (2001) الأدوار التي تقوم بها مديرة المدرسة الحديثة لتحقيق التعاون 
بين المدرسة و الأسرة، ومنها: تعريف الآباء ببرامج المدرسة، وأوجه أنشتطها، وتكوين لجنة من المدرسين للإشر اف على ولى

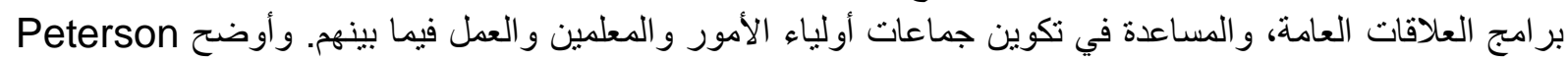

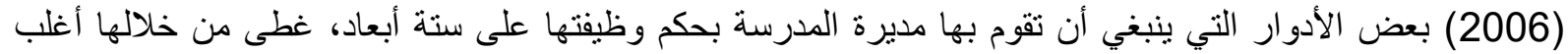

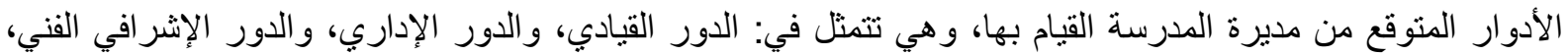

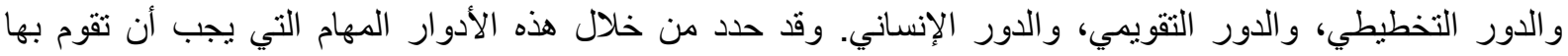

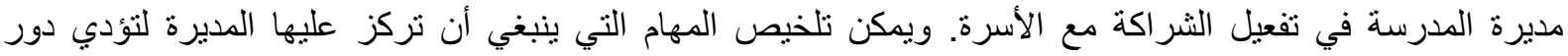

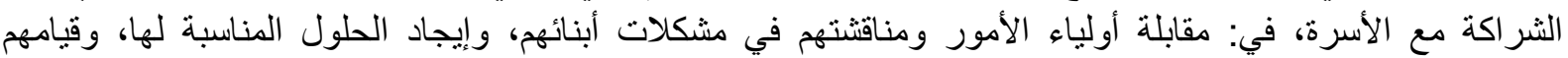

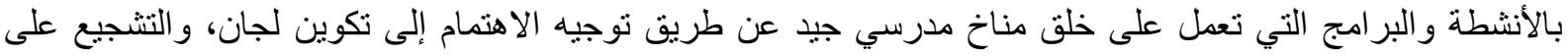

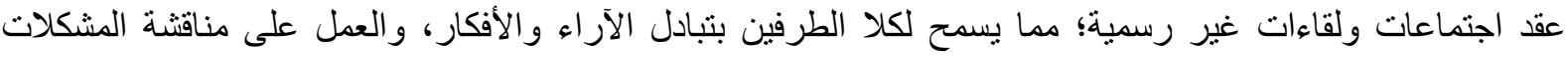

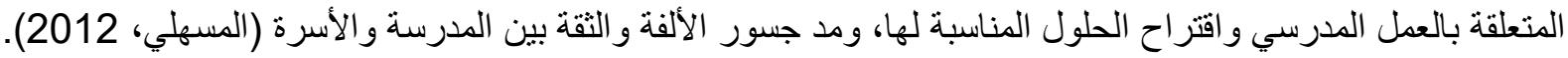
ولتفعيل الثر اكة بين المدرسة والأسرة فو ائد كثيرة لكلا الطرفين؛ فهنالك العديد من الخدمات التي تقدمها المدرسة للأسرة،

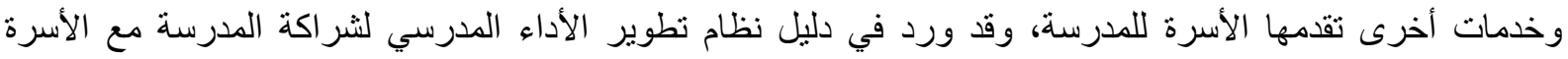

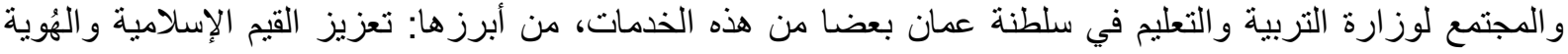

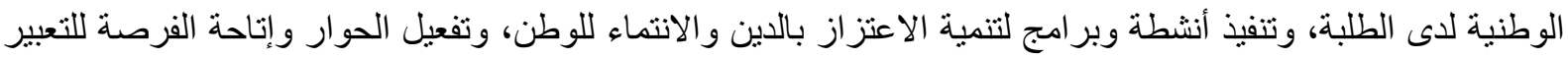

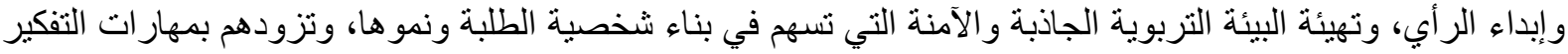

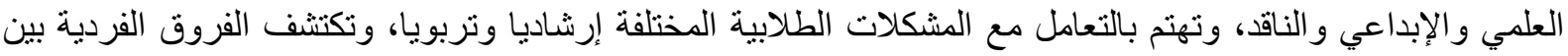

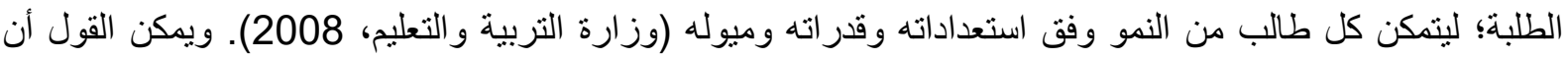

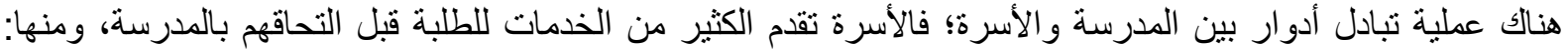

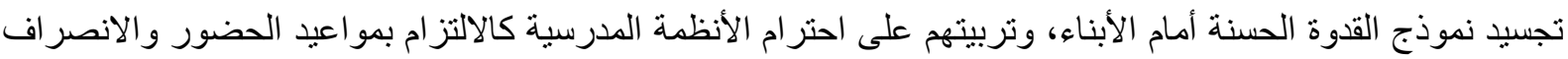

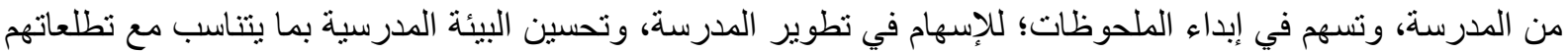

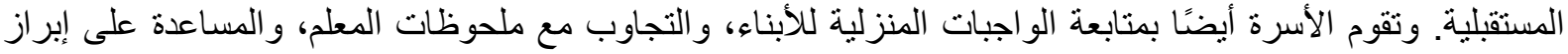

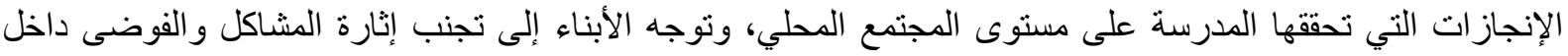

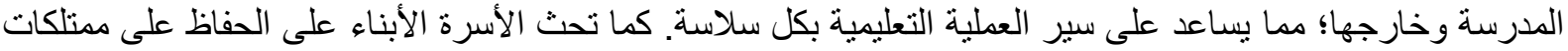

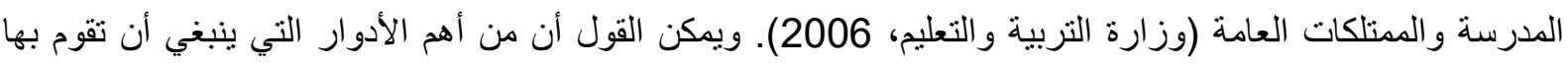

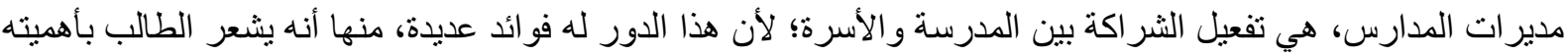

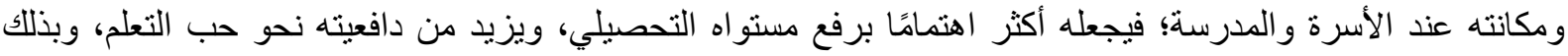

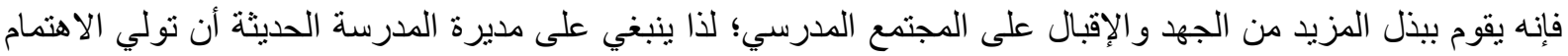

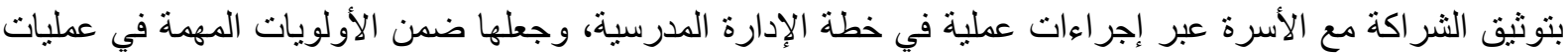

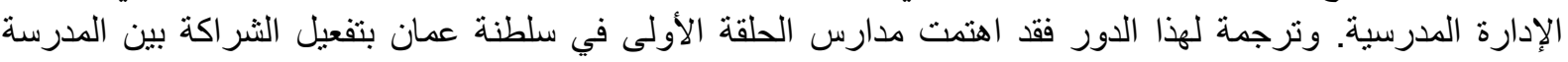

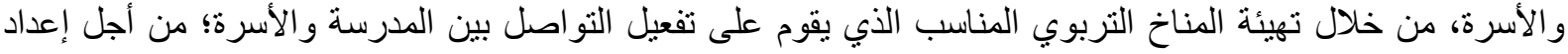

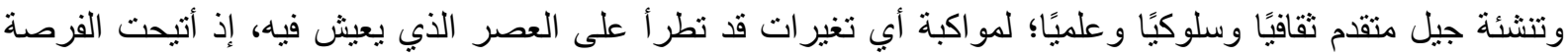

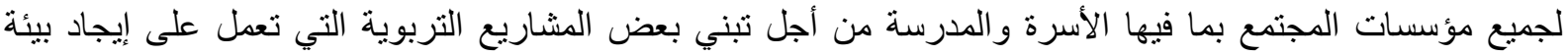

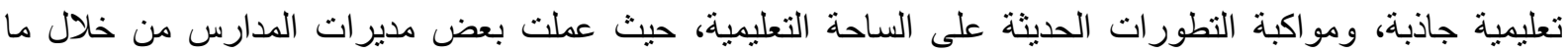

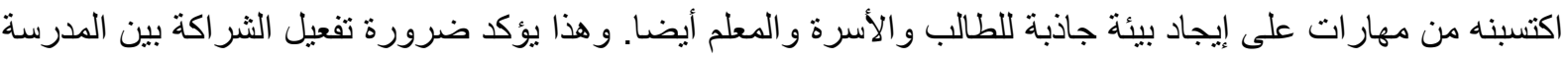

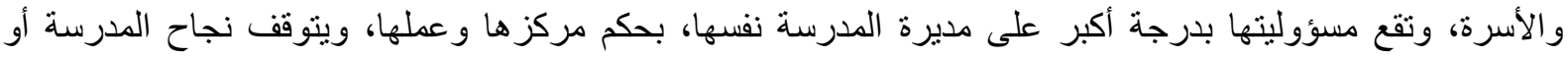

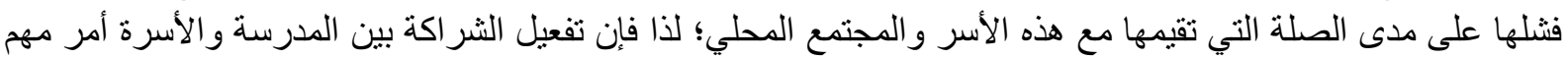

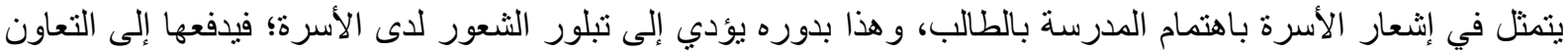

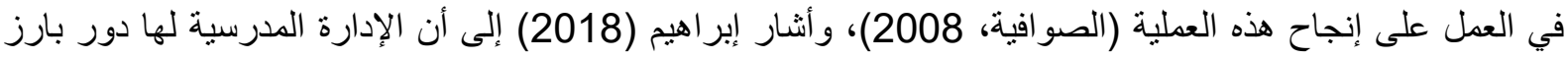

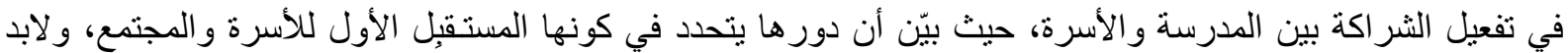

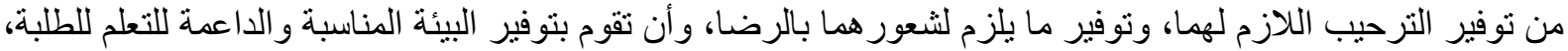

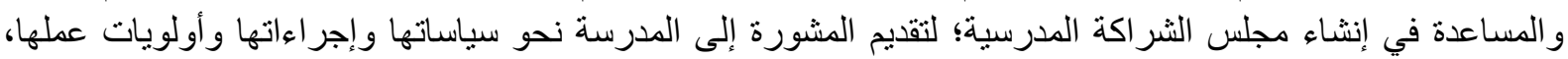

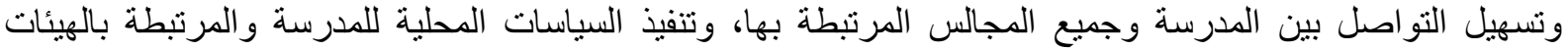
التعليمية المحلية. وكذلك دورها في تعزيز التعاون بين المدرسة والأسرة والمجتمع من خلال رؤية ورسالة متسقة، 
و النظر في استفسارات أولياء الأمور عن القضايا المدرسية والرد عليها. كما تقوم بتشجيع مشاركة الوالدين في عملية

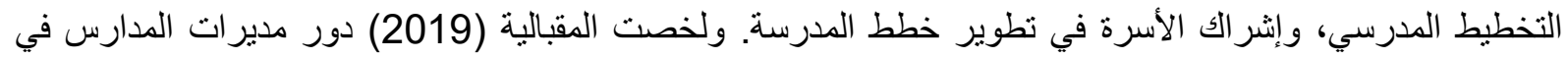

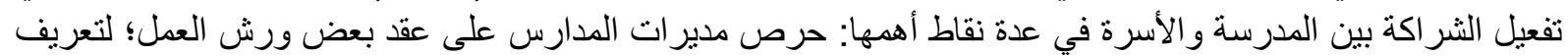

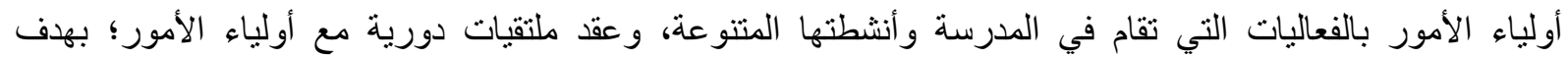

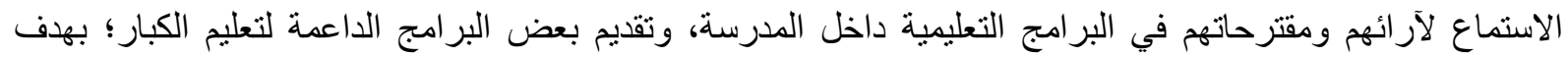

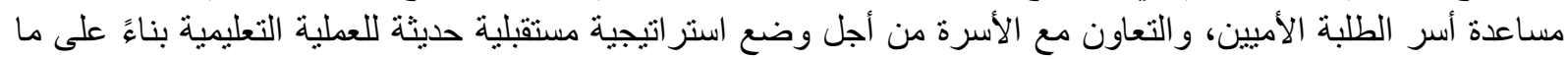

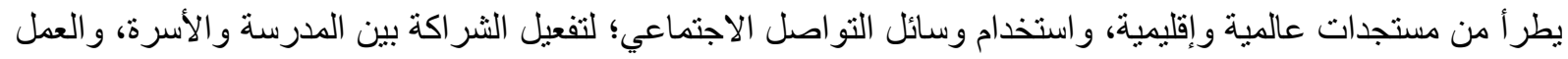

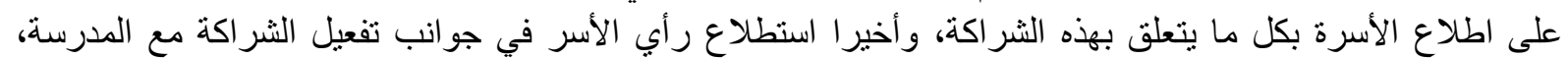

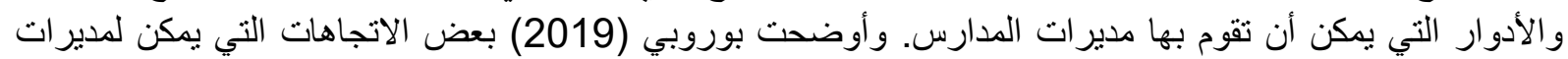

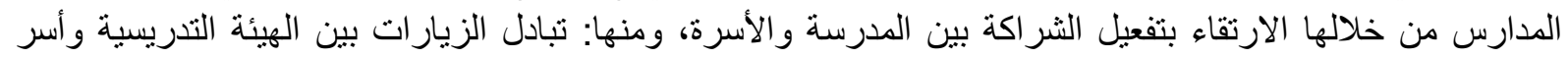

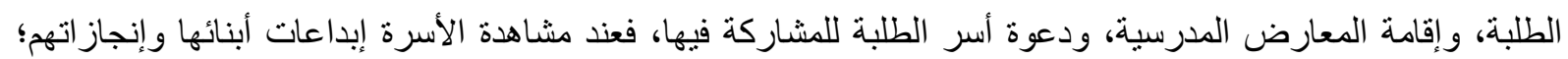

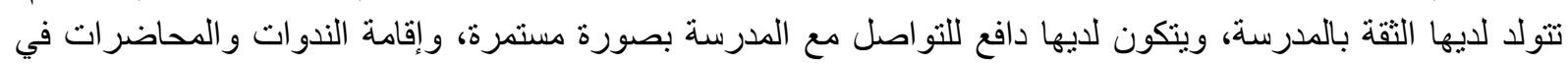

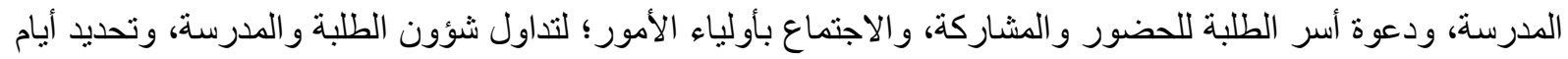

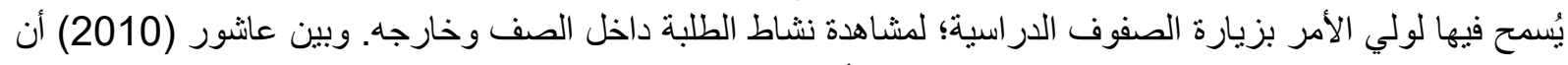

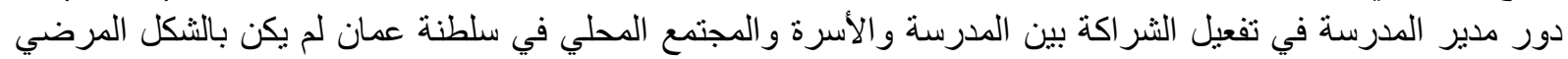

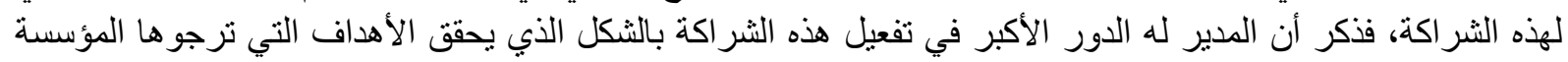

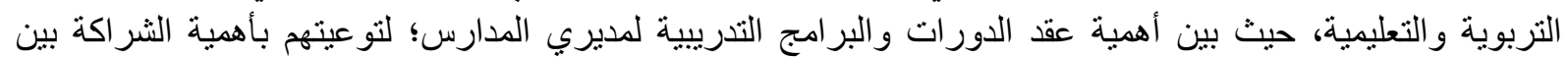

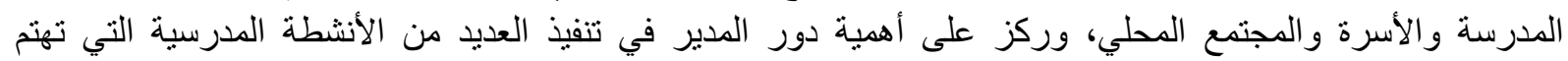

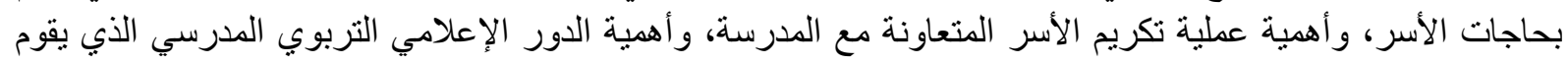

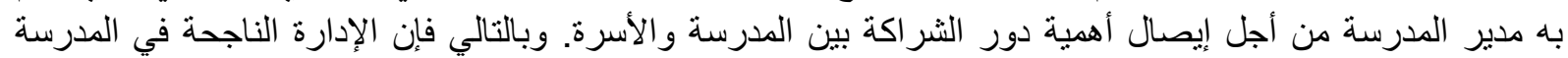

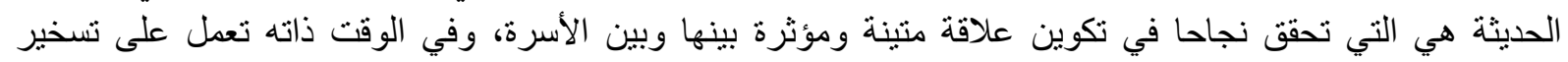

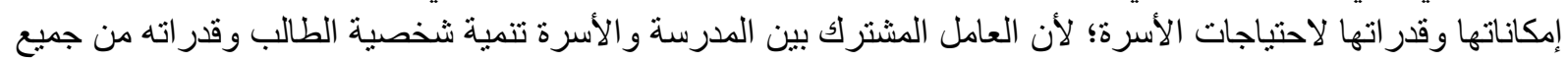

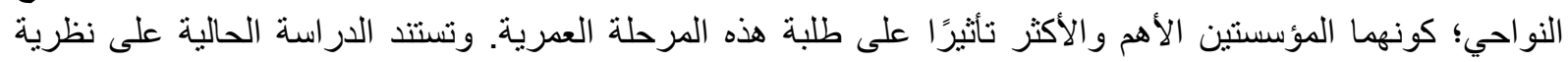

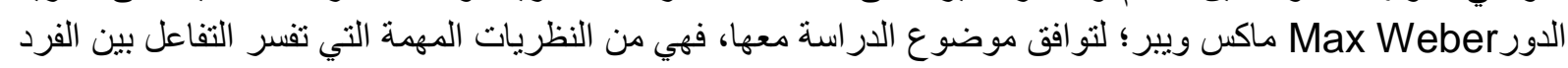

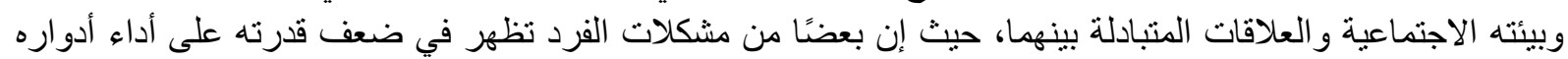

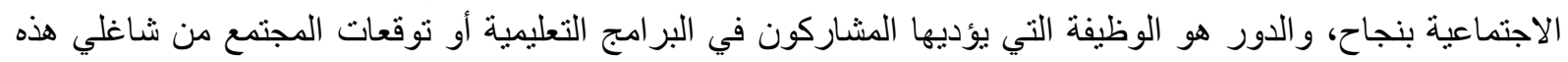

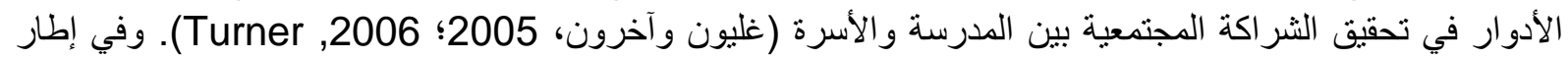

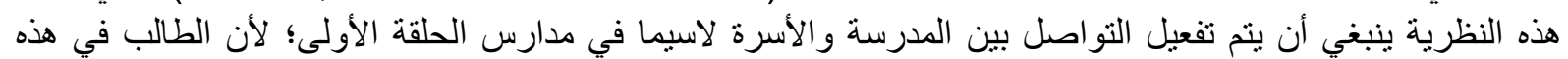

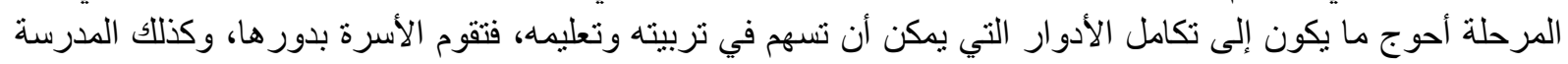

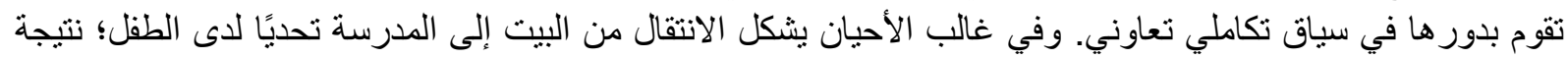

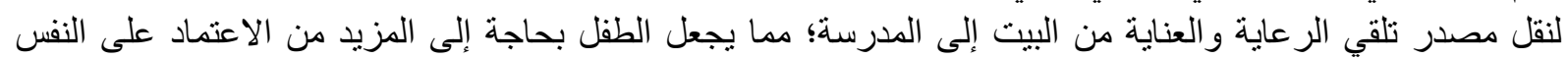

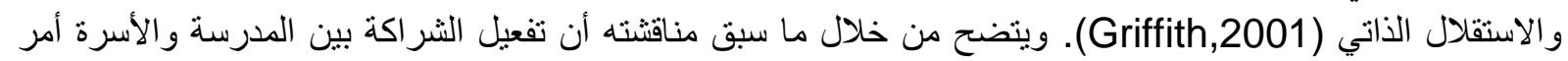

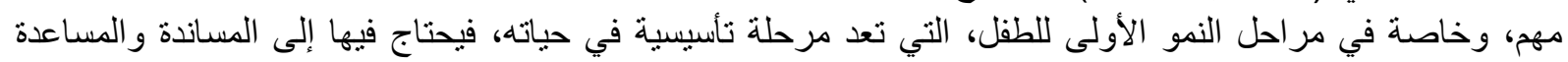

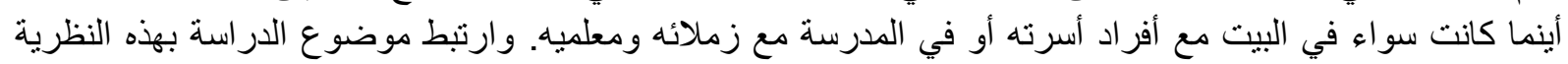

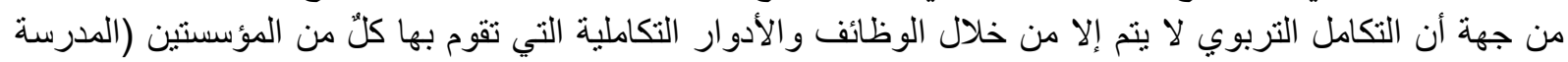

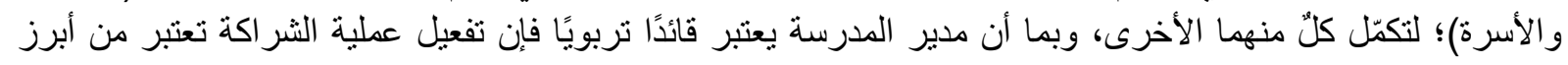

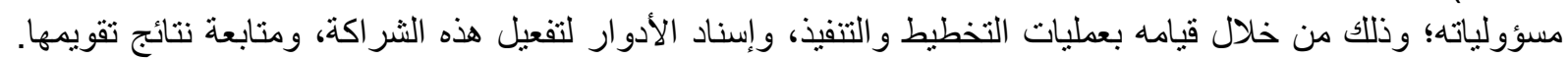

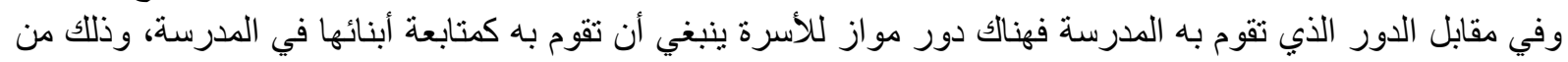

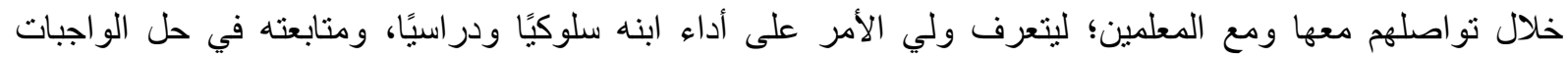

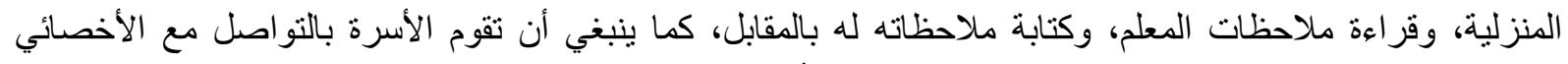

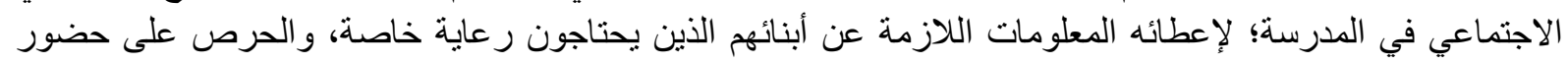

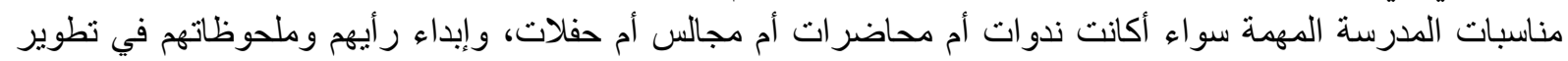

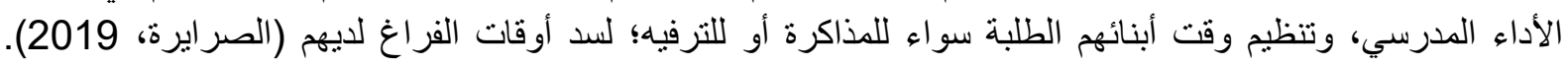

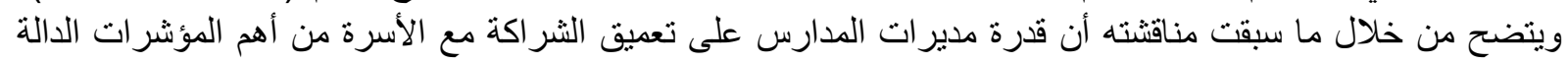


على نجاح المدرسة الحديثة وتميزها في تأدية رسالتها التربوية، فهذه الثر اكة تقود إلى تبادل الأفكار و الخبرات، ورفع

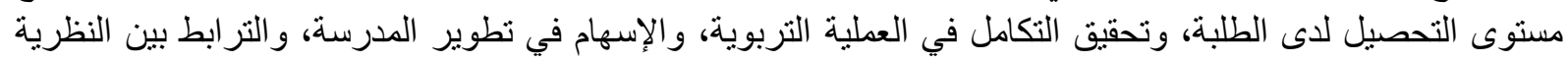

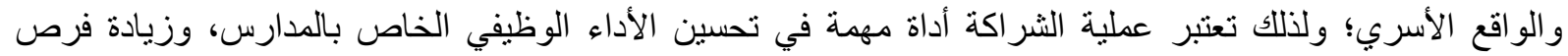

النجاح و التميز.

مشكلة الاراسة

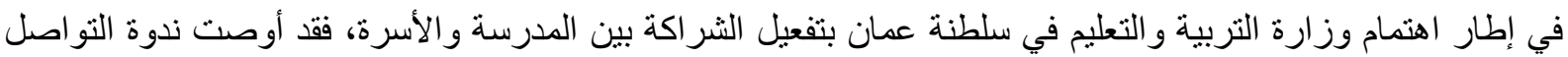

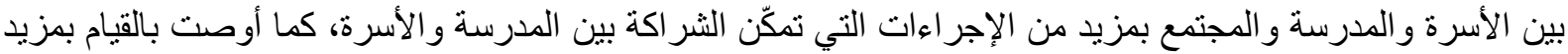

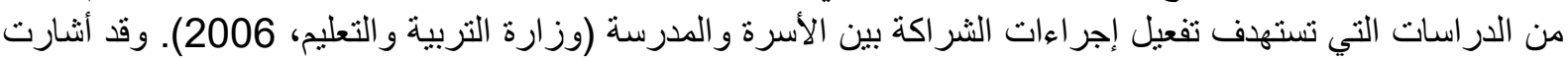

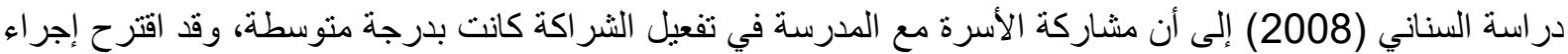

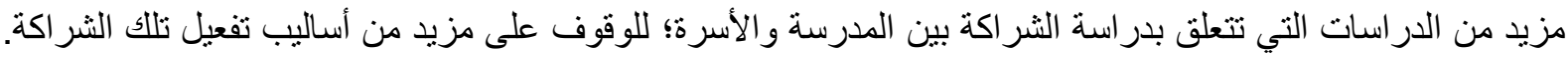

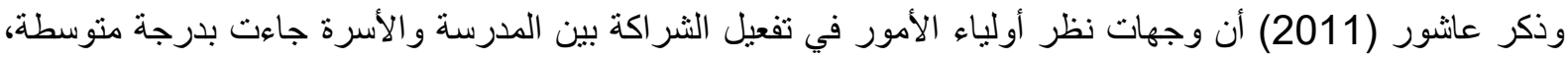

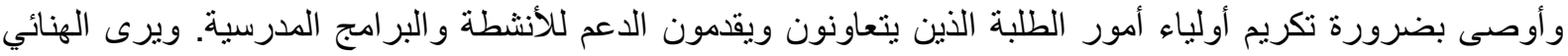

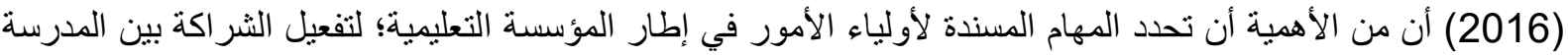

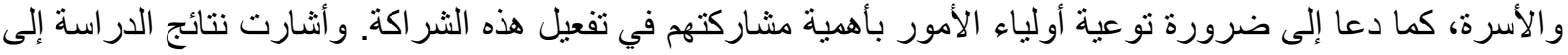

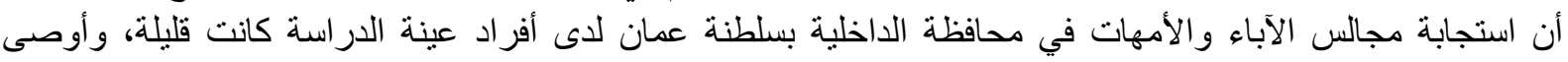

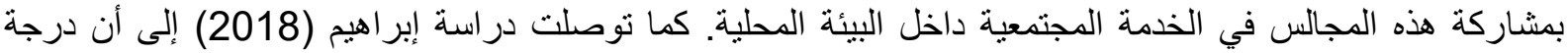

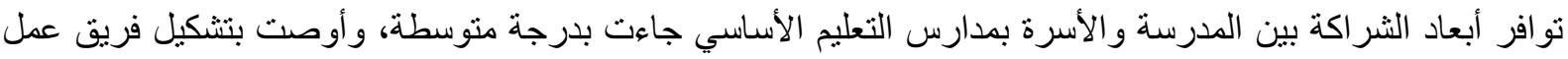

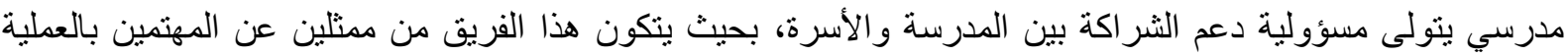

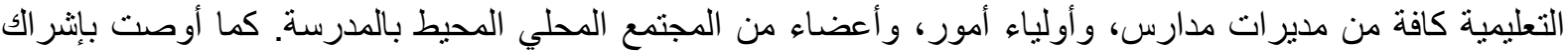

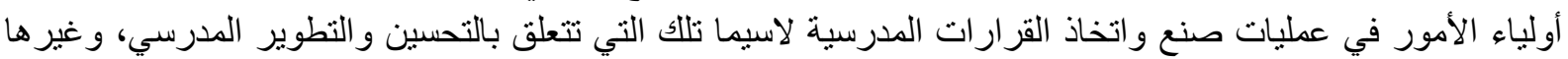
من التوصيات التي تساعد على تفعيل الثر اكة بين المدرسة والأسرة، وتوصلت دراسة المقبالية (2019) إلى أنه لا توات توجد

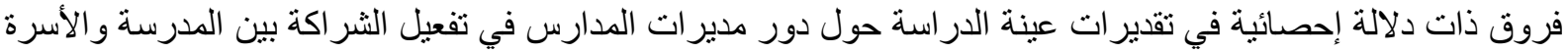

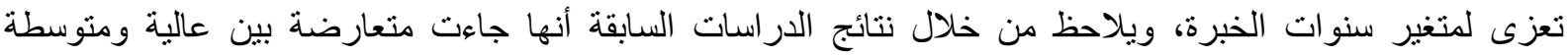
وضعيفة وهذا الأمر قد شكل دافعا للار اسة الحالية لاختيار هذا الموضوع وإن إجر اء الدر اسة عليه. ومن خلال خبرة الباحثئن

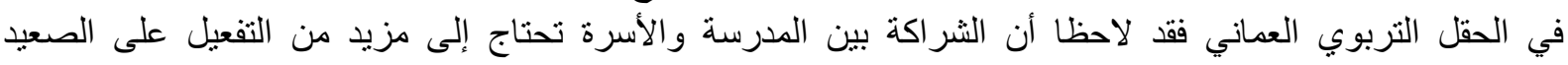

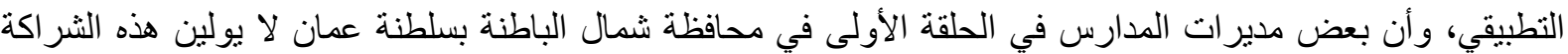

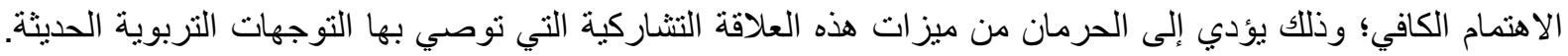

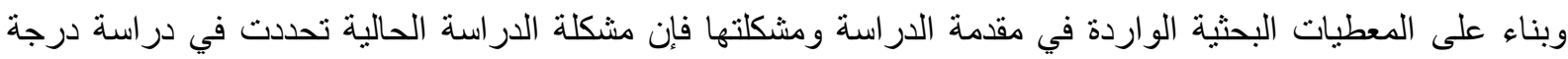
ممارسة مدير ات مدارس الحلقة الأولى بمحافظة شمال الباطنة في سلطنة عمان أدوار الرن في في تفعيل الثر اكة بين المدرسة والأسرة، وينبثق من هذه المشكلة السؤالان الرئئيسان الآتيان:

1. ما درجة ممارسة مديرات مدارس الحلقة الأولى بمحافظة شمال الباطنة في سلطنة عمان أدو ارهن في تفعيل الثر اكة بين المدرسة و الأسرة؛ دارسة 2. هل توجد فروق ذات دلالة إحصائية بين درجة ممارسة مديرات مدارس الحلقة الأولى بمحافظة شمال الباطنة في

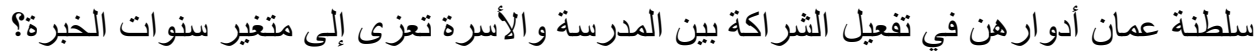

أهداف الدراسة

1. التعرف على درجة ممارسة مديرات مدارس الحلقة الأولى بمحافظة شمال الباطنة في سلطنة عمان أدوار هن في تفعيل الثر اكة بين المدرسة و الأسرة.

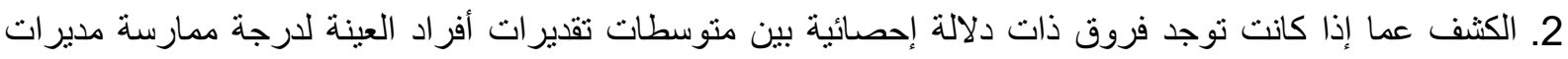

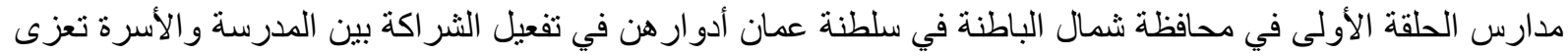

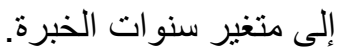


تتبع أهمية الدراسة من طبيعة الموضوع الذي تتناوله، حيث يعد موضو عها من الموضو عات ذات الأبعاد التربوية الهادفة

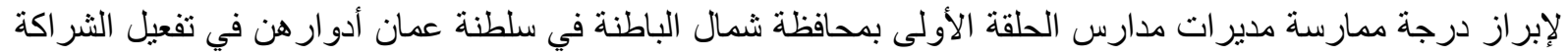

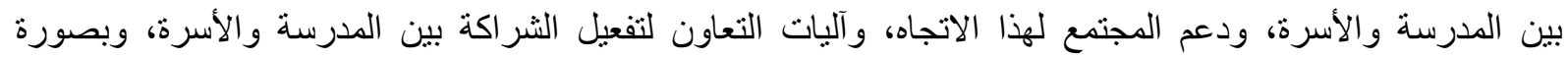

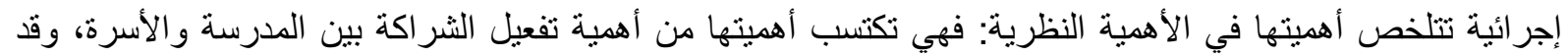

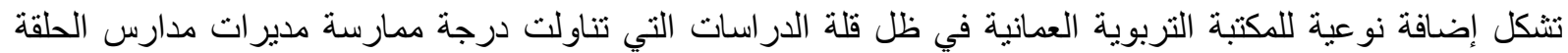

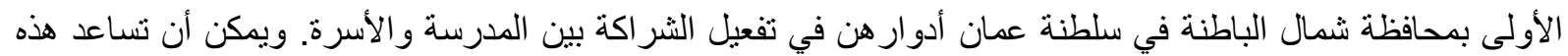

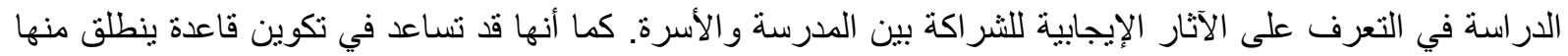

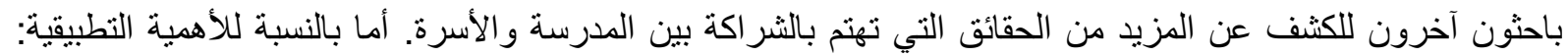

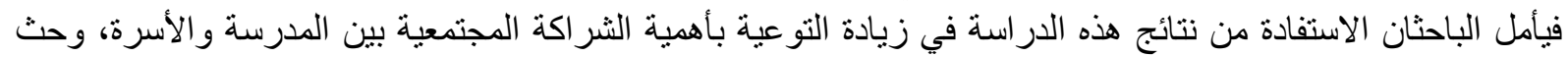

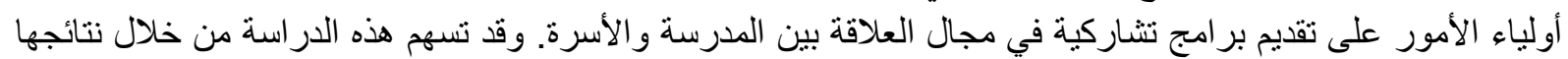

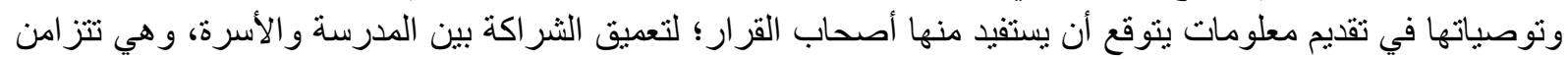
مع الجهود التي تبذلها وزارة التربية و التعليم في سلطنة عمان للارتقاء بمجال القيادة التربوية في العملية التعليمية.

\section{حدود الاراسة}

1. الحدود الموضوعية: التعرف على درجة ممارسة مديرات مدارس الحلقة الأولى بمحافظة شمال الباطنة في سلطنة

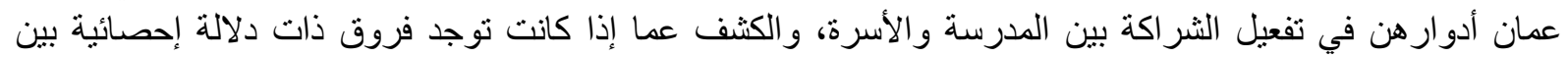

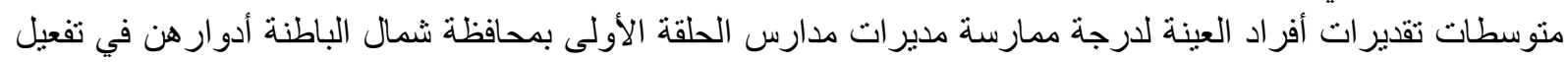

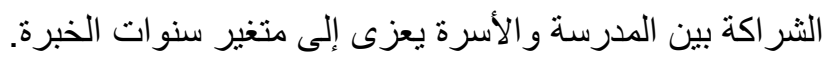
2. الحدود المكانية: محافظة شمال الباطنة في سلطنة عمان.

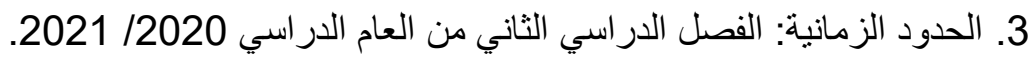
4. الحدود البشرية: عينة من معلمات المجال الأول في مدارس الحلقة الأولى بمحافظة شمال الباطنة.

مصطحات الاراسة

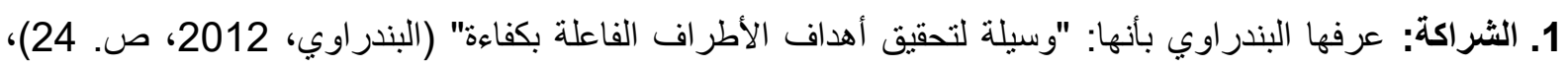

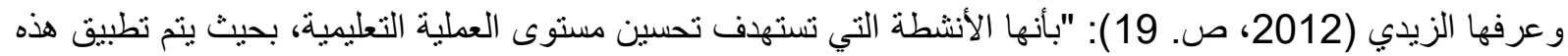

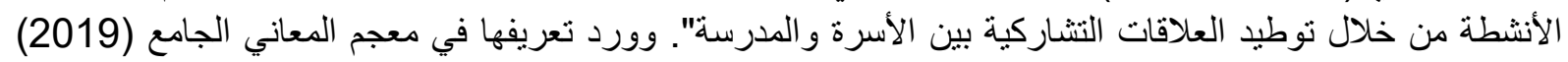

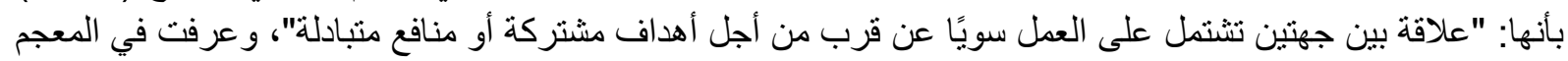

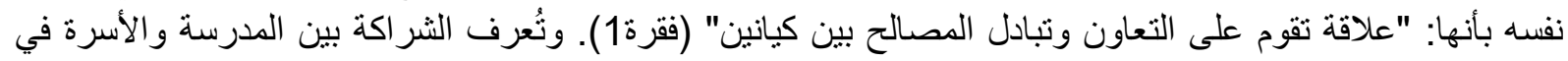

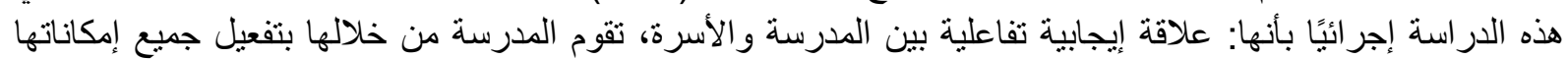

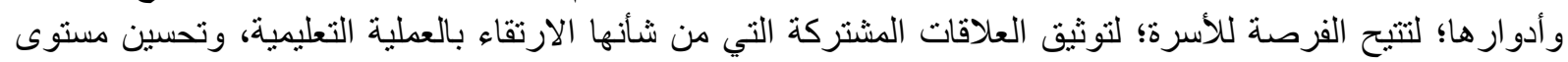

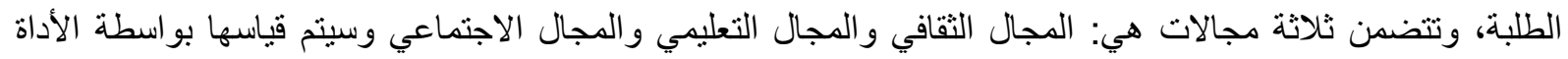

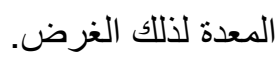

2. محافظة شمال الباطنة التعليمية: إحدى المحافظات التعليمية الو اقعة في شمال سلطنة عمان، وتتميز بالكثافة الطلابية والتعليمية فيها، إذ تعد ثاني أكبر محافظة تعليمية بعد محافظة مسقط.

\section{منهجية الاراسة}

اعتمدت هذه الدراسة على المنهج الوصفي؛ من أجل معرفة درجة ممارسة مديرات مدارس الحلقة الأولى في محافظة

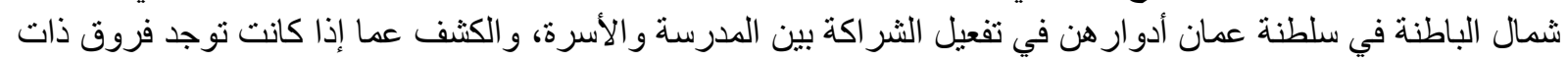

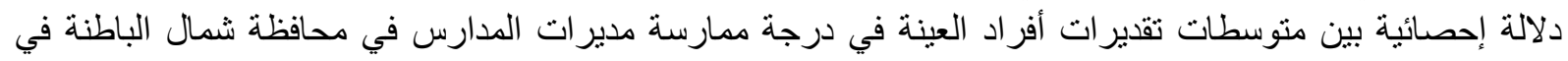

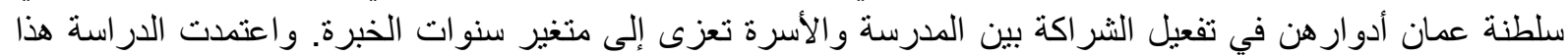


المنهج؛ لأنه يصف الظواهر وصفًا كيفيًا وكيًا، عن طريق جمع المعلومات وتحليلها، ثم الكثف عن العيقات العلاقات بين

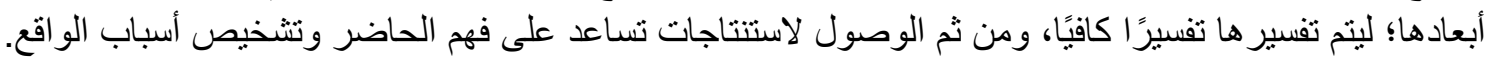

\section{مجتمع الدراسة والعينة}

تكون مجتمع الدر اسة من جميع معلمات المجال الأول بمدارس الحلقة الأولى بمحافظة شمال الباطنة في سلطنة عمان في

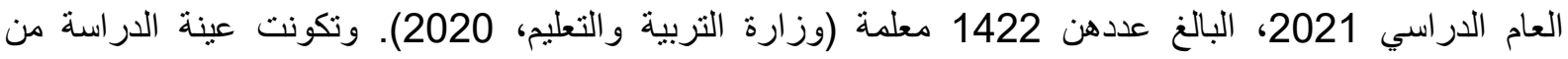
17.2\% من معلمات المجال الأول في مدارس الحلقة الأولى بمحافظة شمال الباطنة في سلطنة عمان، وبلغت الرة العينة 244 معلمة، تم اختيار هن بالطريقة المتيسرة.

أداة الدراسة

استبانة مغلقة؛ كونها من أكثر وسائل الحصول على البيانات من أفراد العينة استخدامًا وانتشارًا، وتكونت من قسمين:

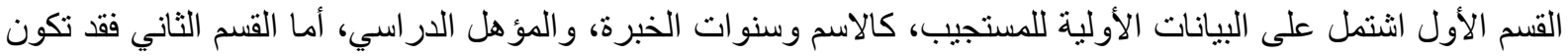

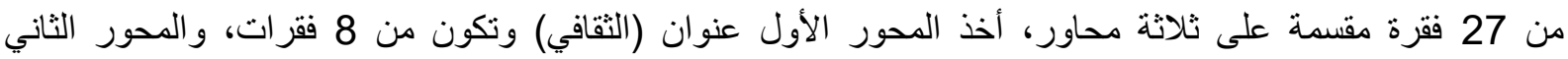

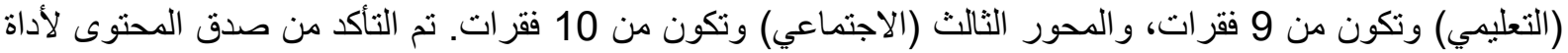
الدراسة من خلال صدق البنود، وصدق التمثيل، ونم استخراج معامل الثبات بطريقة الاتساق الداخلي لمعادلة كronbach's Alpha

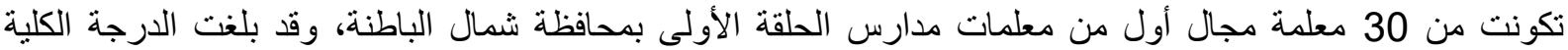

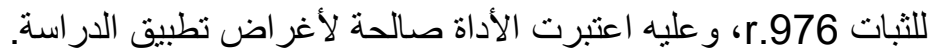

\section{إجراعات الاراسة، والمعالجات الإحصائية}

بناء خطة الدر اسة من حيث: المقدمة، ومشكلة الدر اسة و أسئلتها، و أهمية الدر اسة، و أهدافها، وحدود الدر اسة، و التعريفات

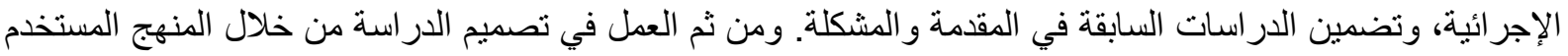

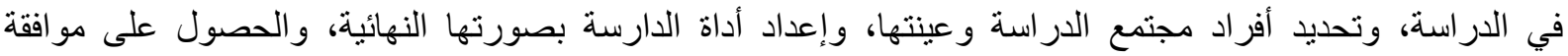
الجهات ذات الاختصاص، متمثلة في المكتب الفني للار اسات و التطوير بوزارة التربية والتعليم، ودائرة تنمية الموارد

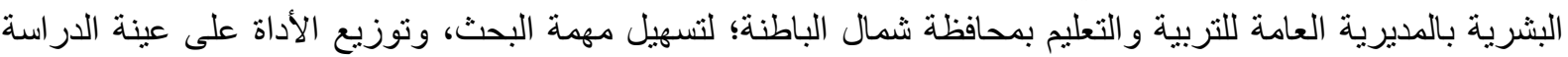

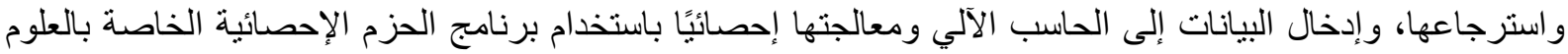

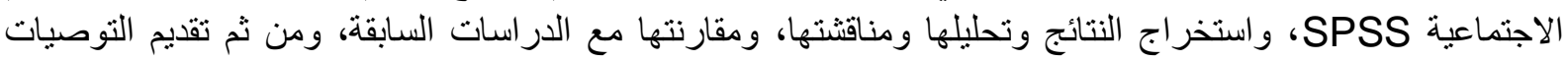

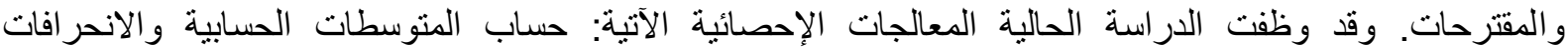

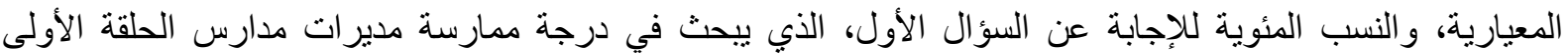

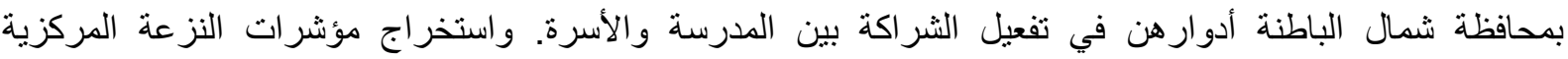

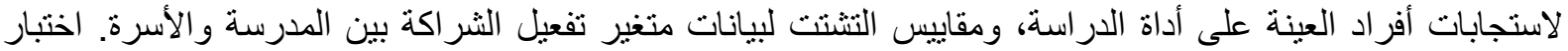

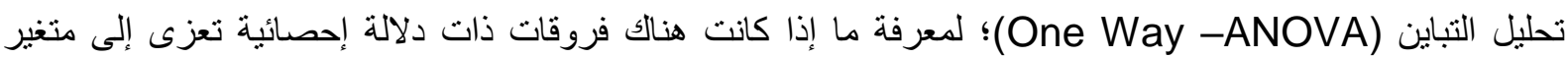

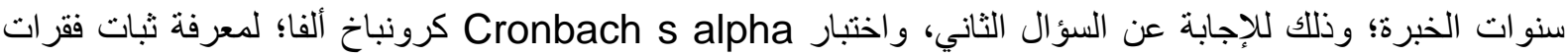

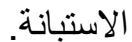

نتائج الدراسة ومناقشتها والتوصيات والمقترحات للإجابة عن أسئلة الدراسة تم البدء بالإحصاء الوصفي متمثلا في مؤشرات النزعة المركزية: المتوسط الحسابي، و الوسيط، و المنو ال لاستجابات أفر اد العينة على أداة الدراسة، والأه ويوضح الجدول 1 هذه النتائج. 
مؤشرات النزعة المركزية لبيانات متغير تفعيل الشر اكة بين المدرسة والأسرة

\begin{tabular}{|c|c|c|c|}
\hline المنو ال ل & الوسيط & المتوسط الحسابي & مؤشر ات النزعة المركزية \\
\hline 4.77 & 4.30 & 4.19 & المستوى العام \\
\hline
\end{tabular}

من الجدول 1 اتضح أن مؤشرات النزعة المركزية لمتغير الثر اكة بين المدرسة والأسرة جاءت قيمها قريبة من بعضها،

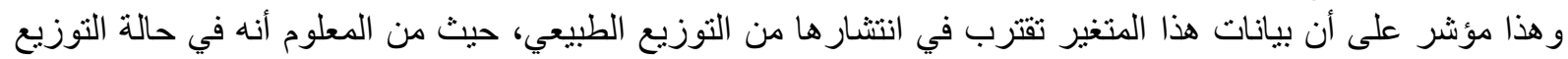

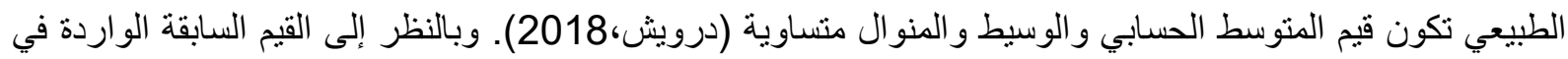
الجدول 1 اتضح أنها منقاربة فيما بينها، و هذا مؤشر على أن البيانات تقترب في انتشار ها من التوزيع الطبيعي.

\section{مقياس التشتت}

كما نم استخر اج مقاييس التشتت؛ لمعرفة مدى اقتراب البيانات من وسطها الحسابي، و الجدول 2 وضح هذه النتائج. جدول2 مقاييس التشتت لبيانات متغير تفعيل الثر اكة بين المدرسة والأسرة

\begin{tabular}{|c|c|c|c|c|c|c|c|c|}
\hline المعبار ي & قأعة & أدنى قيمة & المدى & التفلطح & الالتواء & التباين & ف الانحر ا & المتغير \\
\hline 0.04 & 5 & 1.37 & 3.63 & 1.82 & -1.22 & 0.44 & 0.66 & الثعيل اكة \\
\hline
\end{tabular}

اتضح من الجدول 2 أن قيمة التباين لمتغير تفعيل الثراكة بين المدرسة والأسرة (0.44)، وبلغت قيمة الانحراف

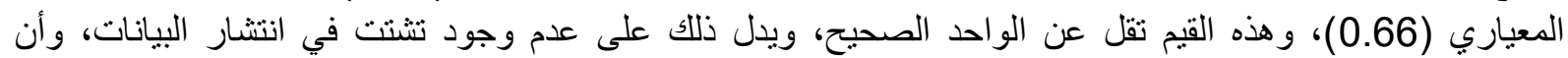

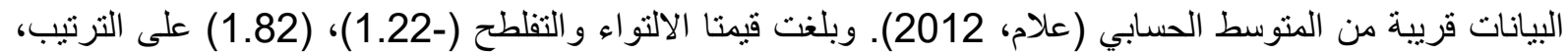

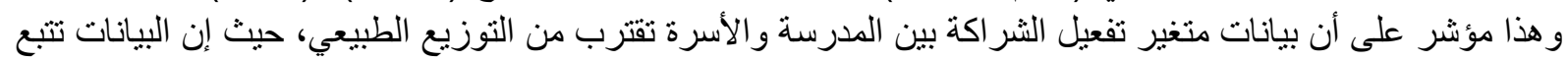

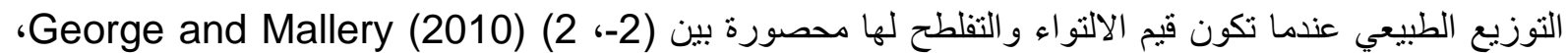
ويوضح الشكل 1 انتشار بيانات متغير تفعيل الثر اكة بين المدرسة والأسرة.

\section{شكل1: توزيع بيانات متغير تفعيل الثراكة بين المدرسة والأسرة}

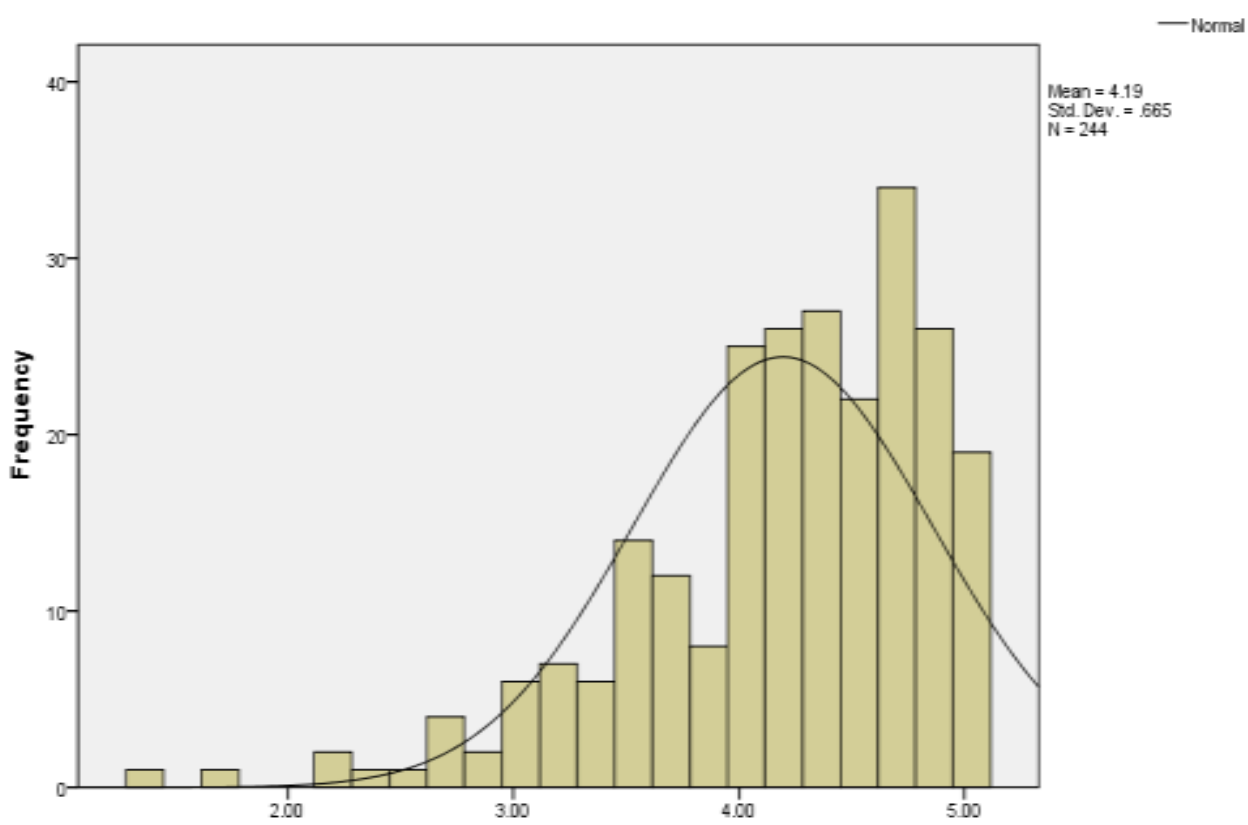


تبيّن من الثكل 1 أن بيانات منغير تفعيل الثر اكة بين المدرسة والأسرة تتوزع بانتظام تقرييًا عن يمين قيمة المتوسط

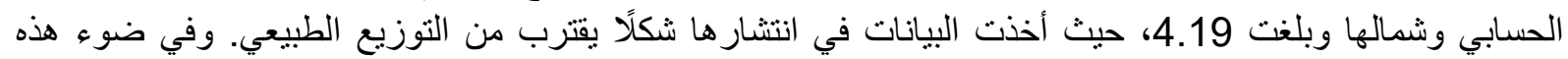

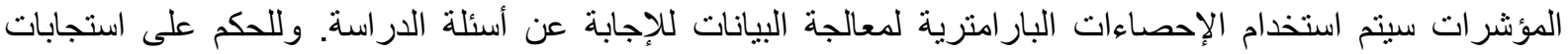

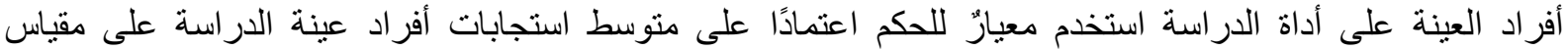

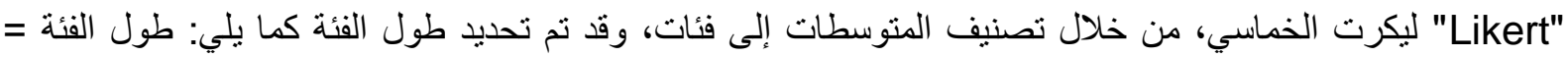

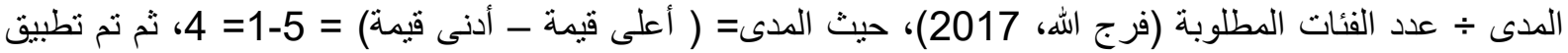

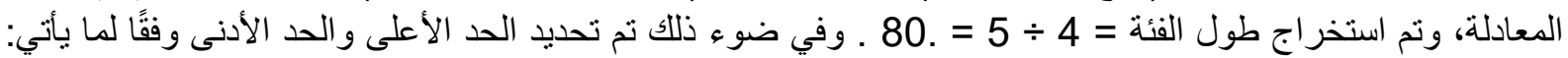

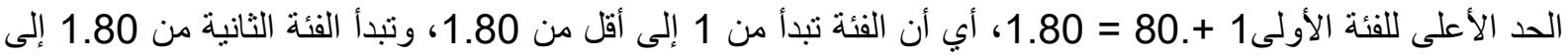
أقل من 2.60، وهكذا في كل مرة يتم إضافة طول الفئة 0.80 للحد الأعلى من الفئة السابقة، وعليه نم تحديد الفئات الموضحة في جدول 3.

جدول3 معيار الحكم على استجابات أفر اد عينة الدراسة وفقًا للمتوسط الحسابي

\begin{tabular}{|c|c|}
\hline المستوى & فئات المتوسط الحسابي \\
\hline ضعيف جدًا & من 1 - أقل من 1.80 \\
\hline ضعيف & من 1.80 - أقل من 2.60 \\
\hline متوسط & من 2.60 - أقل من 3.40 \\
\hline عالٍ & من 3.40 - أقل من 4.20 \\
\hline عالِ جدًا & من 4.20 - 5 \\
\hline
\end{tabular}

النتائج المتعلقة بالسؤال الأول ومناقشتها

1. ما درجة ممارسة مدير ات مدارس الحلقة الأولى بمحافظة شمال الباطنة في سلطنة عمان أدوارهن في تفعيل الثر اكة الثة

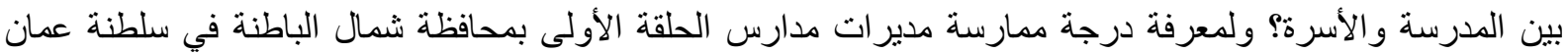

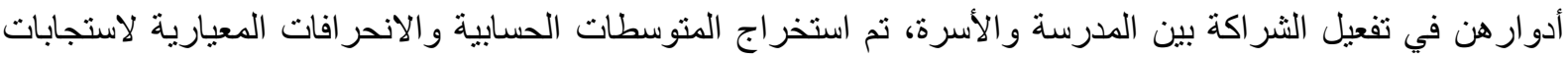
أفر اد العينة على محاور أداة الدر اسة، و الجدول 4 يبين هذه النتائج.

جدول4 المتوسطات الحسابية والانحر افات المعيارية لدرجة ممارسة مديرات مدارس الحلقة الأولى في محافظة شمال الباطنة

\begin{tabular}{|c|c|c|c|c|}
\hline المستوى & 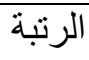 & الانحر اف & المتوسط & المحاور \\
\hline عالِ جدًا & 1 & 0.61 & 4.31 & تفعيل الثر اكة في المجال الثقافي \\
\hline عالِ جدًا & 2 & 0.71 & 4.23 & تفعيل الثر اكة في المجال التعليمي \\
\hline عالِ & 3 & 0.78 & 4.04 & تفعيل الشر اكة في المجال الاجتماعي \\
\hline عالِ & & 0.66 & 4.19 & سط الكلي \\
\hline
\end{tabular}

تبيّن من الجدول 4 أن المنوسطات الحسابية لاستجابة أفراد عينة الدراسة على محاور درجة ممارسة مديرات مدارس

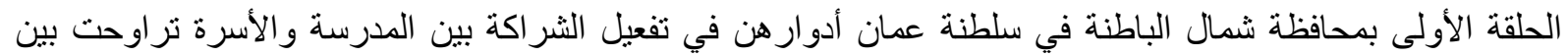

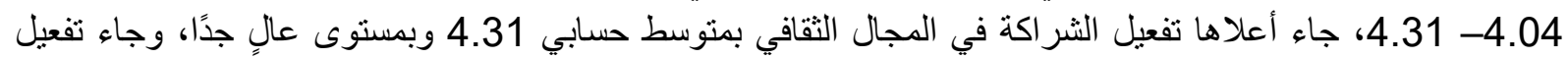

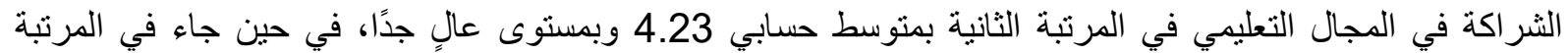
الثالثة والأخيرة تفعيل الثراكة في المجال الاجتماعي بمتوسط حسابي 4.04، وبمستوى عالٍ، وبلغ المنوسط الكلي فئي 
للاستبانة 4.19، و هذا يدل على أن درجة ممارسة مدير ات مدارس الحلقة الأولى بمحافظة شمال الباطنة في سلطنة عمان

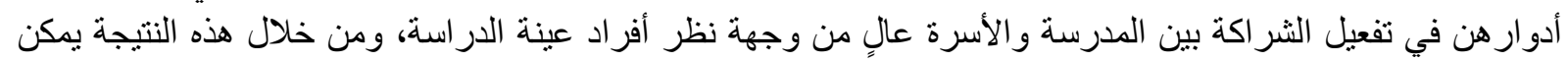

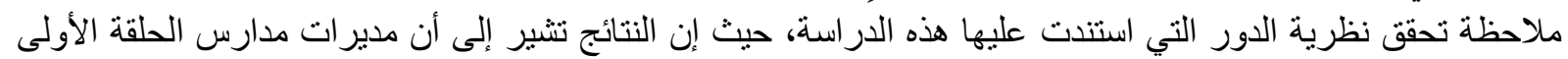

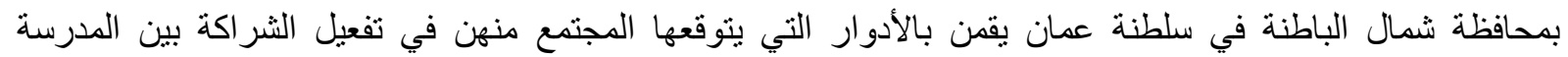

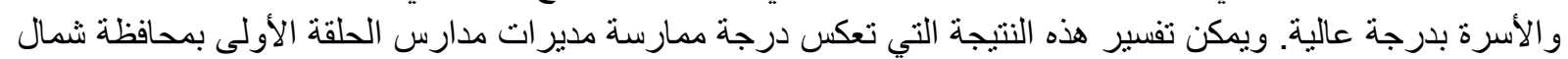

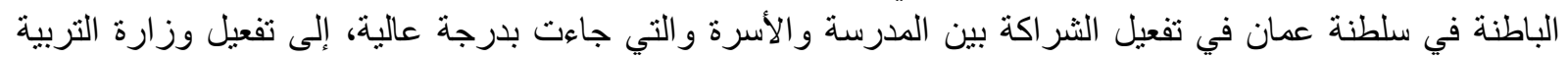

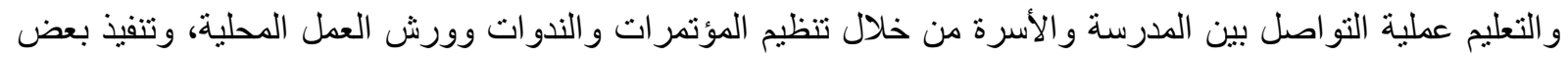

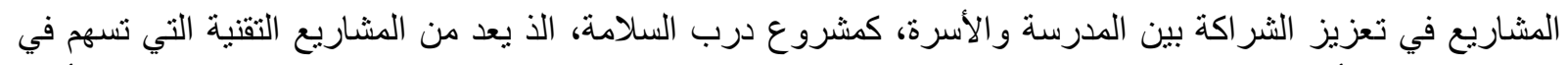

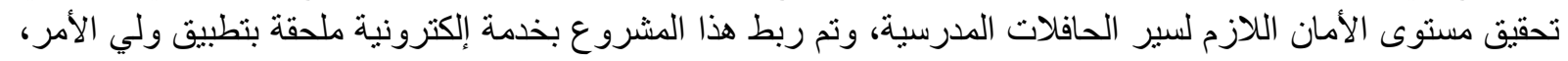

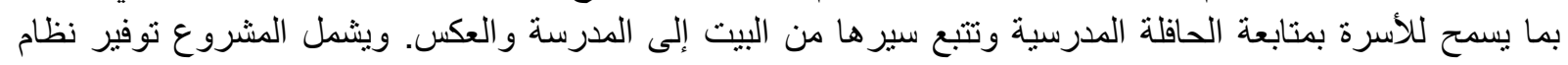

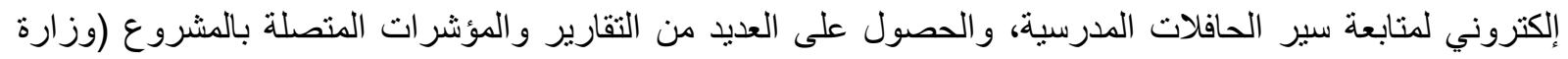

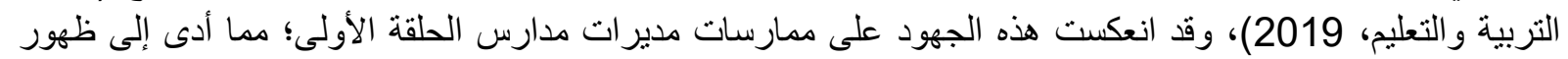

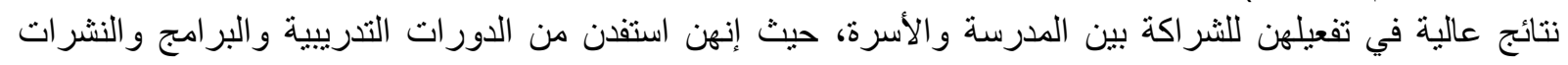

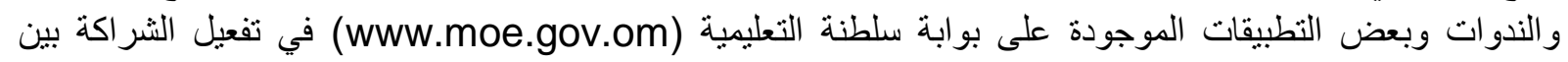

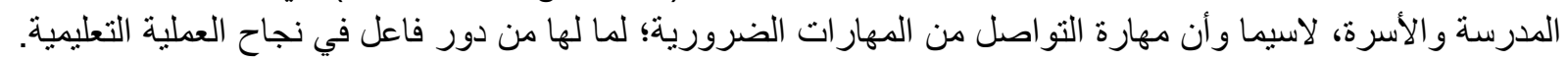

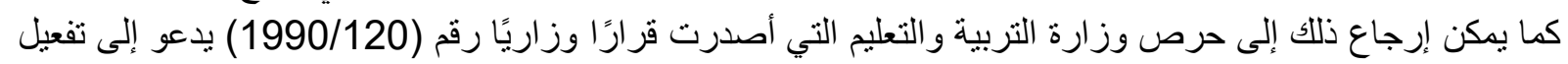

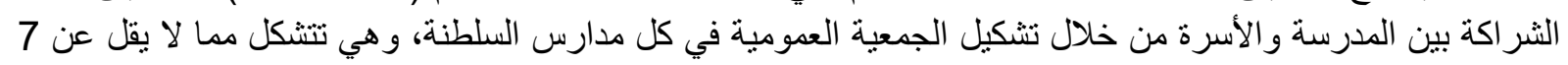

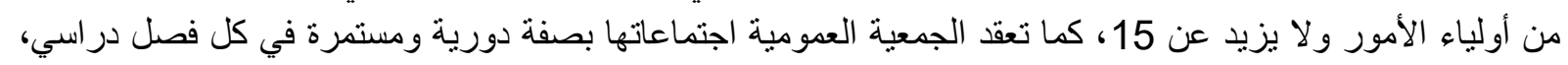

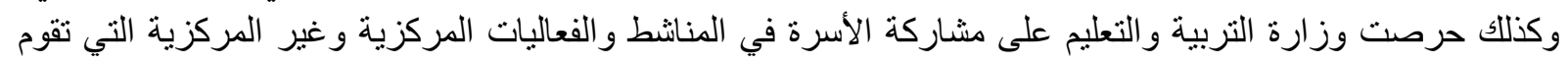

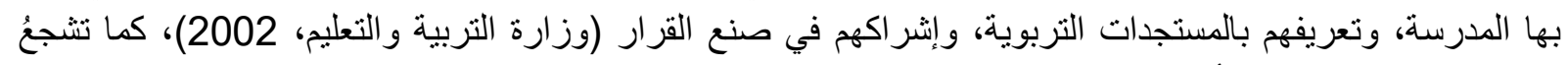

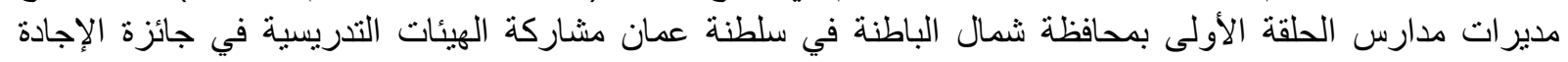

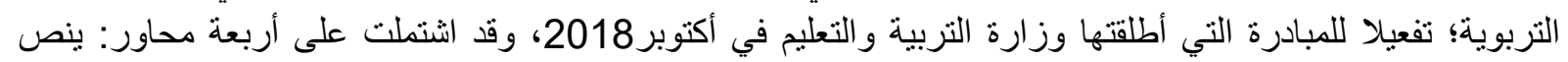

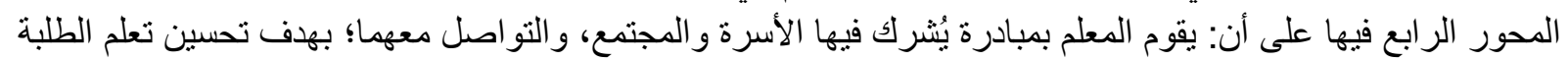

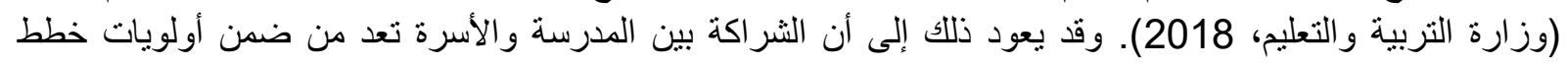

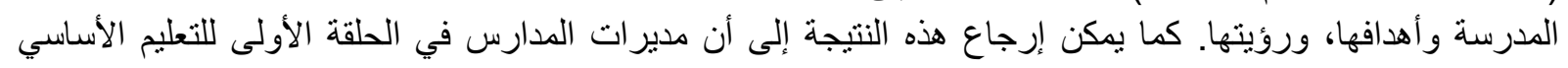

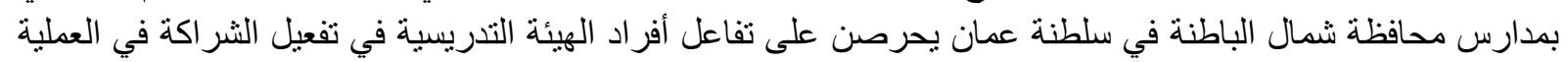

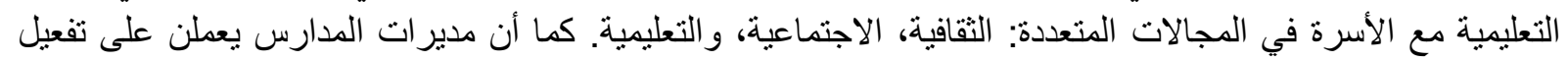

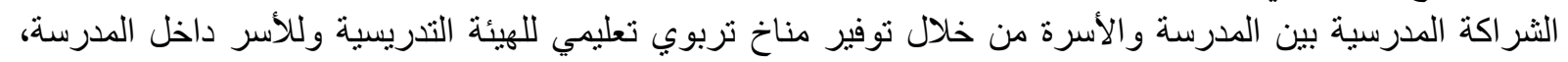

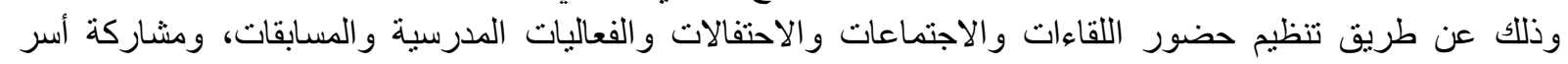

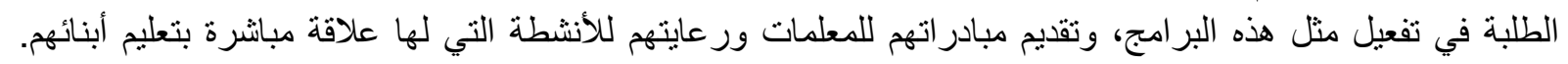

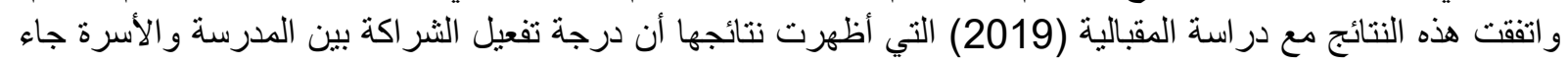

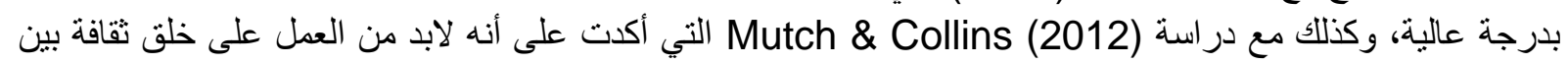

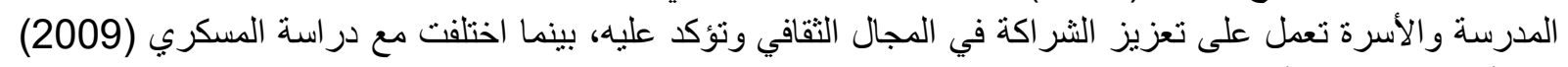

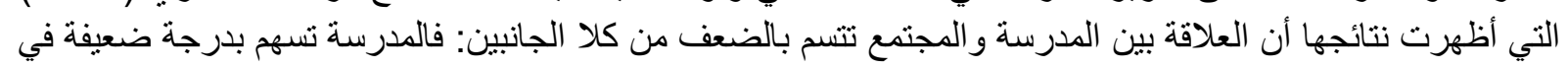

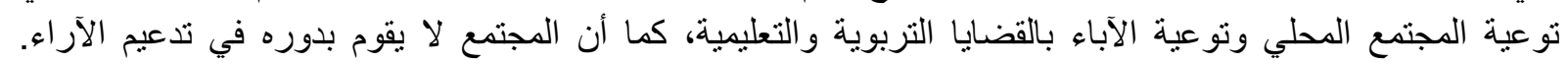

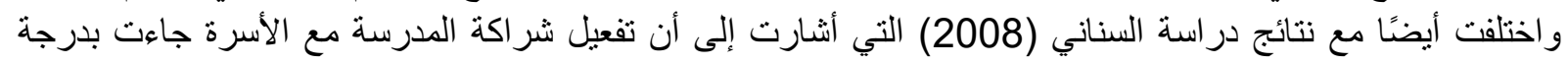

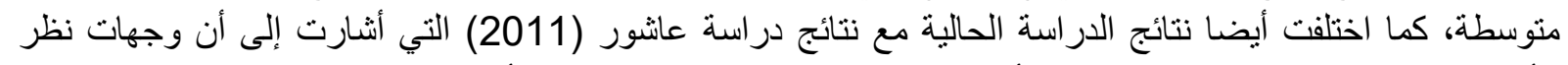

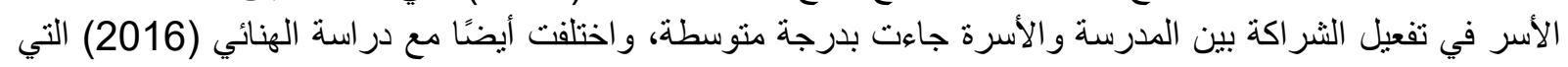

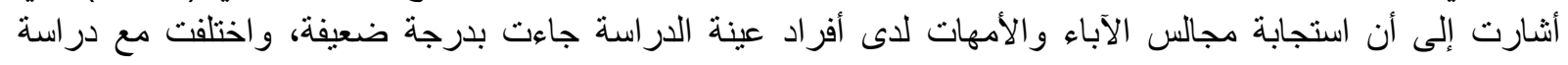

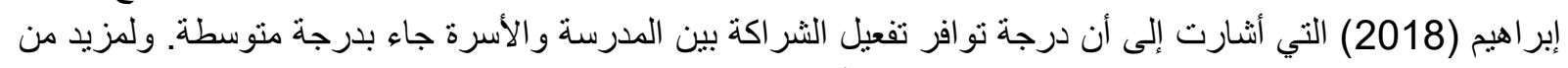

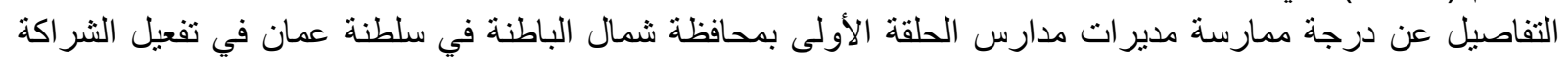

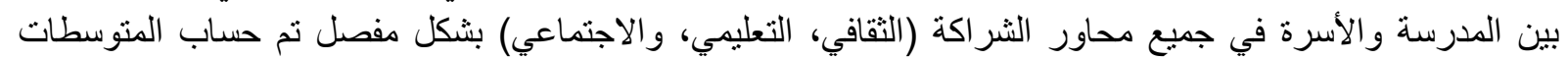

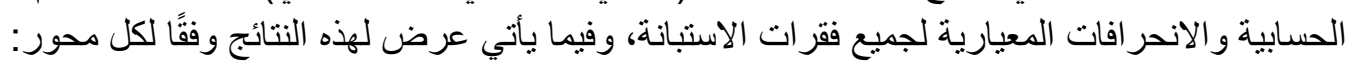


المتوسطات الحسابية والانحر افات المعيارية لفقرات محور تفعيل الثر اكة في المجال الثقافي

\begin{tabular}{|c|c|c|c|c|}
\hline المستوى & المعياري & 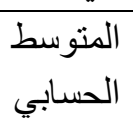 & الفقر ات & الرتبة \\
\hline عالِ جدًا & 0.67 & 4.54 & تلاتصنال بأسرة المدرسة ملفات الطلبة بييانات كافية؛ & 1 \\
\hline عالِ جدًا & 0.79 & 4.48 & تلتعامل مديرة المدرسة مع الأسرة كشريك ف فاعل & 2 \\
\hline 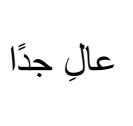 & 0.79 & 4.38 & 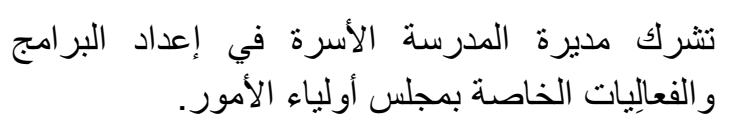 & 3 \\
\hline عالِ جدًا & 0.77 & 4.35 & 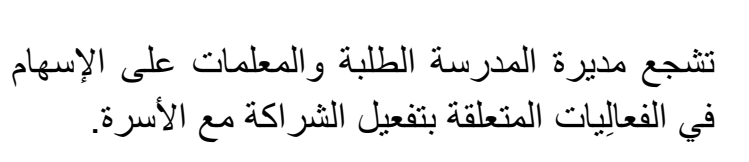 & 4 \\
\hline عالِ جدًا & 0.80 & 4.33 & 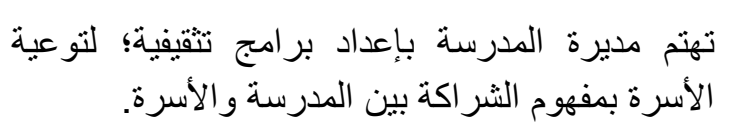 & 5 \\
\hline عالِ جدًا & 0.81 & 4.29 & 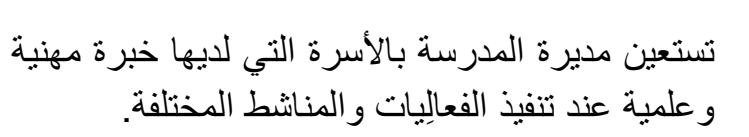 & 6 \\
\hline عالِ جدًا & 0.85 & 4.27 & والطلبة والمعلمات مديرة المدرسة الإذاعة المعيل الثدرسية؛ لتعريف & 7 \\
\hline عالِ جدًا & 0.84 & 4.25 & 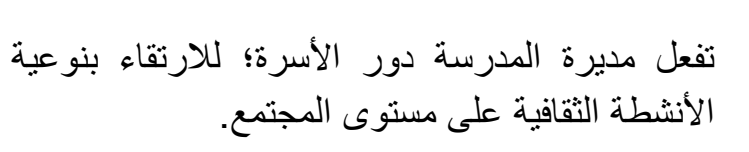 & 8 \\
\hline عالِ جدًا & 0.92 & 4.24 & الدعو مديرة المدرسة أولياء الأمور لزيارة المعارض المدار المدرسية. & 9 \\
\hline عالٍ & 1.05 & 3.96 & بتظف مديرة المدرسة دورات تربوية لأولياء الأمور؛ & 10 \\
\hline 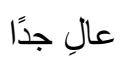 & 0.61 & 4.31 & مر اكة في المجال الثقافي ككل & 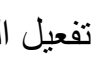 \\
\hline
\end{tabular}

اتضح من الجدول 54 أن المتوسطات الحسابية لفقرات محور تفعيل الثراكة في المجال الثقافي تراوحت بين 3.96 ـ

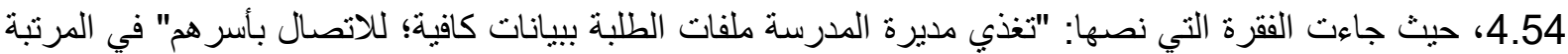
الأولى بمتوسط حسابي 4.54 وبمستوى عالٍ جدًا، وبانحر اف معياري 0.67، وجاءت في المباء المرتبة الأخيرة الفقرة التي

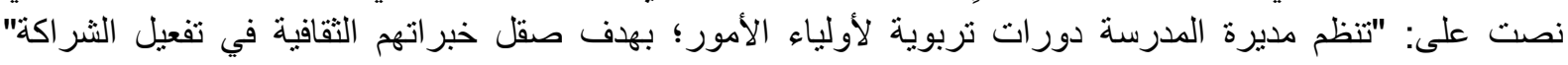
بمتوسط حسابي بلغ 3.96 وبمستوى عالٍ، وبانحر اف معياري 1.05. وبلغ المتوسط الحسابي لتفعيل الثر اكة في المجال الثقافي ككل 4.31، وهذا يدل على أن درجة ممارسة مديرات مدارس الحلقة الأولى بمحافظة شمال الباطنة في سلطنة

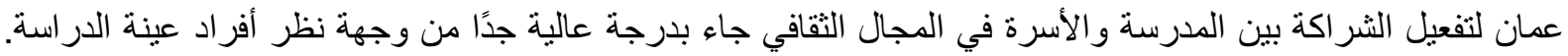

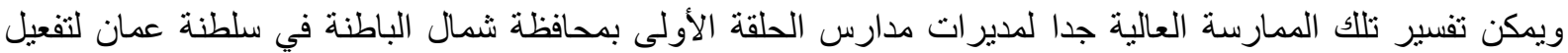

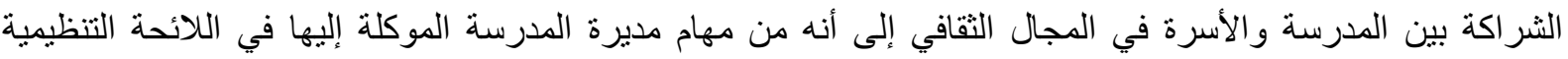
للمدارس الصادرة بالقرار الوزاري 1991/21: أن يُفعل دور المدرسة كمؤسسة نربوية لخدمة المجتمع، ويشارك أولياء 
الأمور في الأنشطة التربوية والثقافية والفعاليات من خلال إقامة بر امج داخل المدرسة وخارجها (وزارة التربية و التعليم،

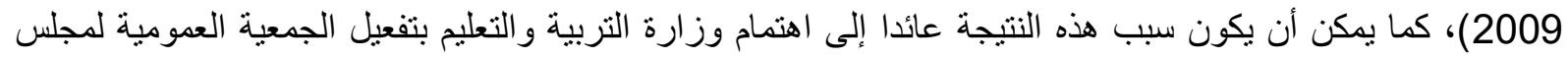

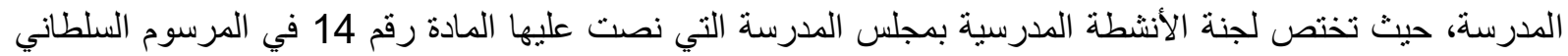

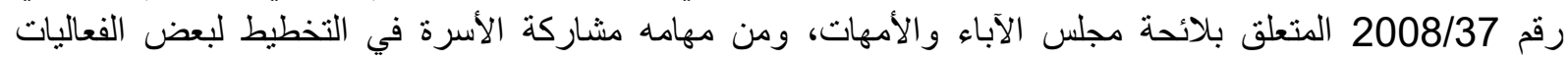

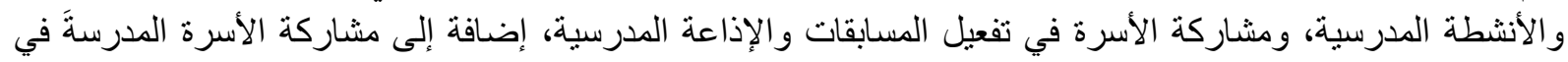

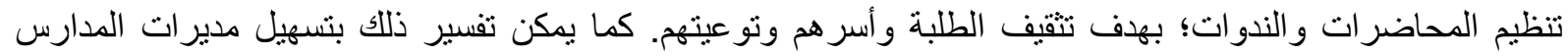

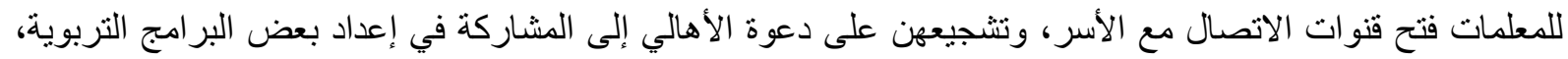

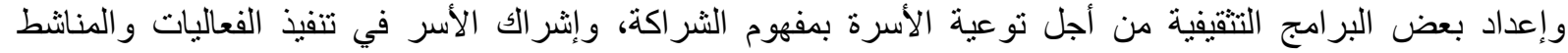

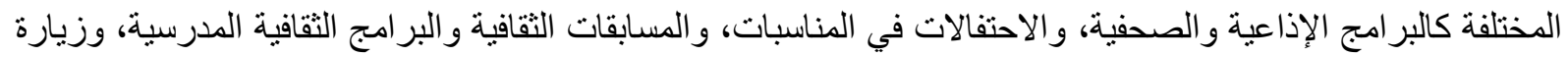

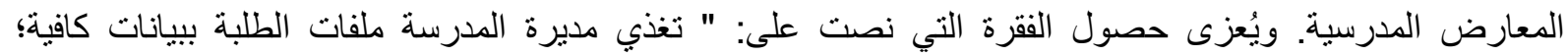

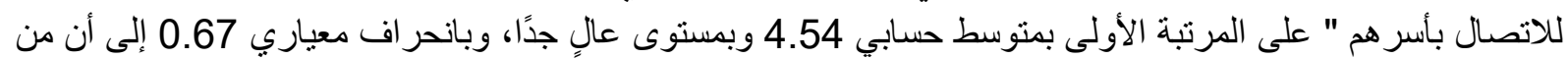

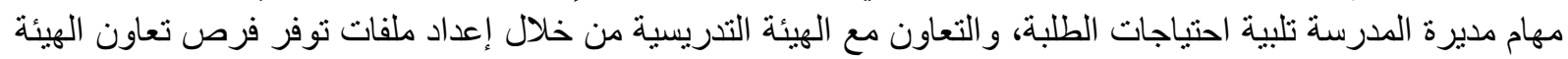

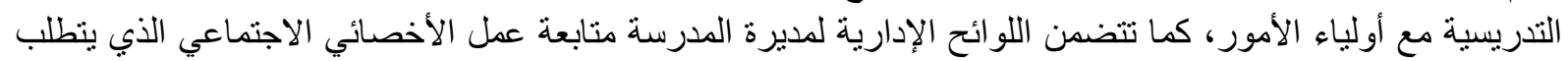

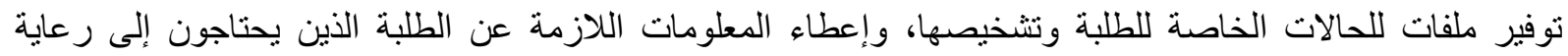

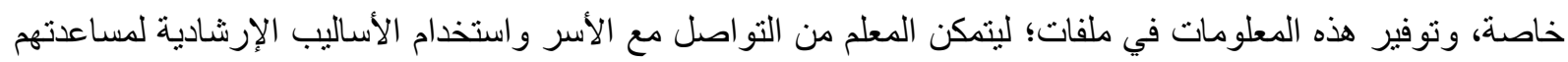

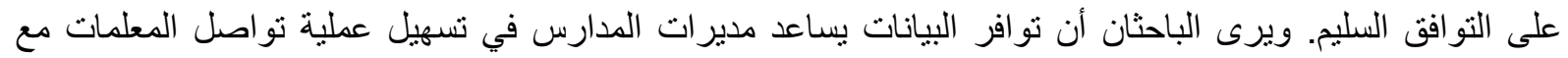

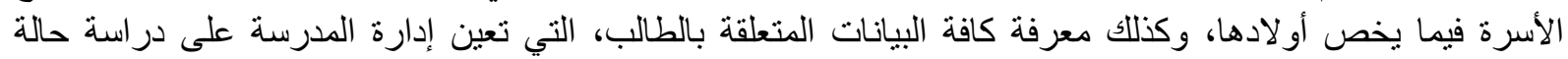

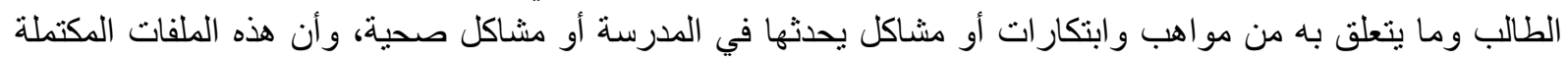

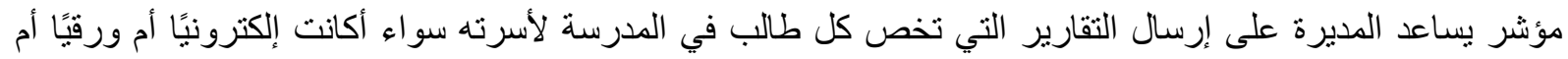

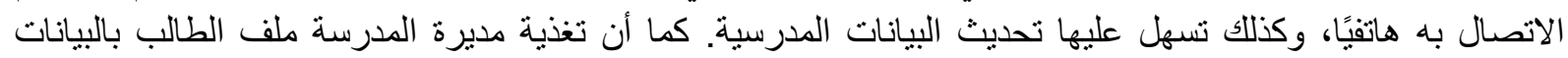

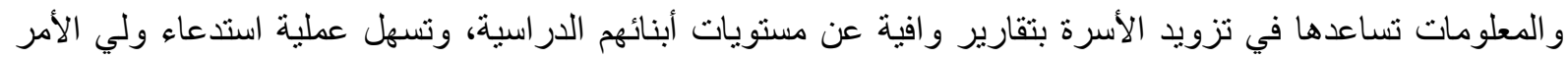

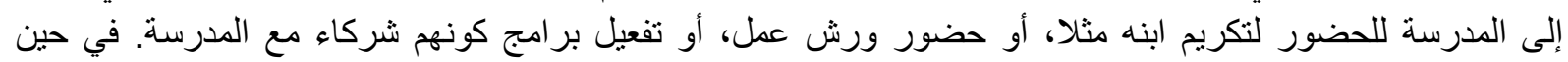

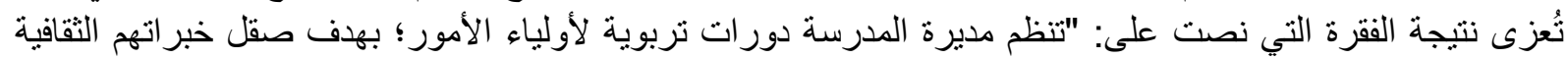

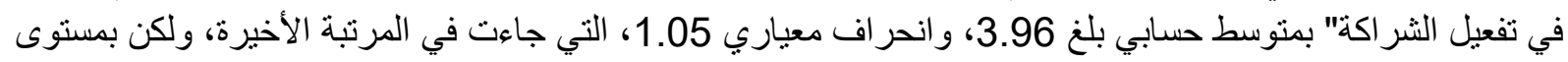

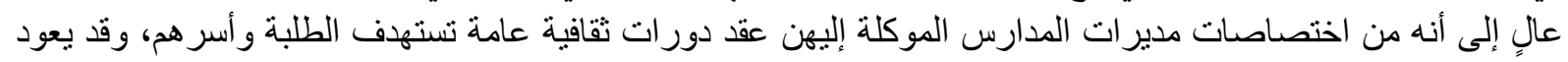

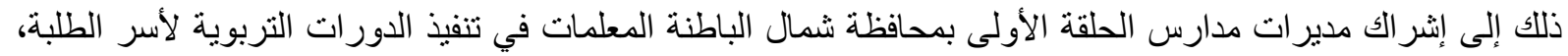

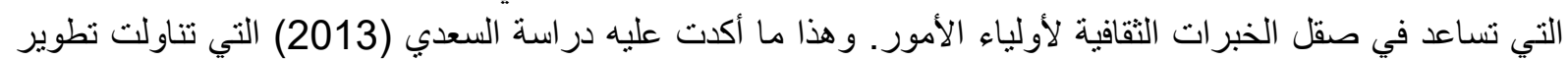

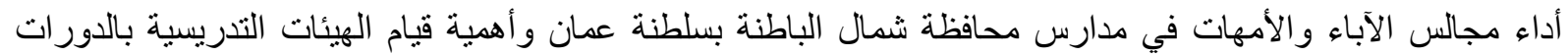

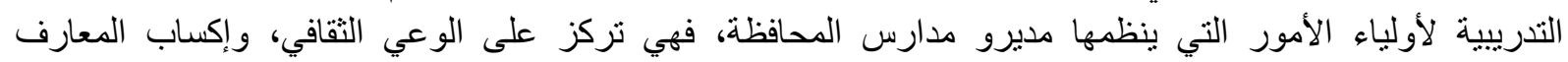
و المهارات في مختلف الجو انب؛ مما يعزز تفعيل الثر اكة بين المدرسة والأسرة.

المحور الثاني: تفعيل الثراكة في المجال التعليمي

جدول 6

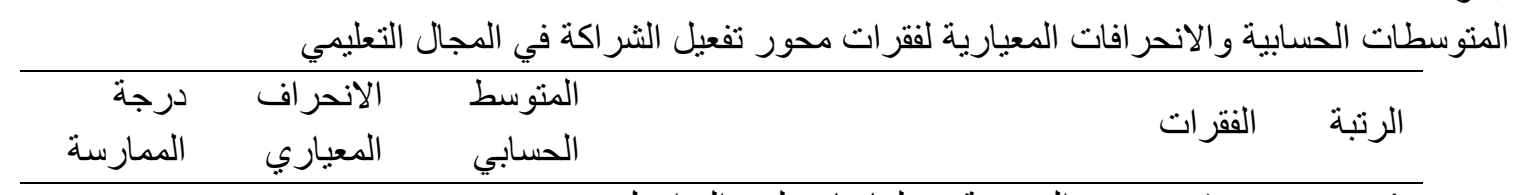

\begin{tabular}{|c|c|c|c|}
\hline عالِ جدًا & 0.69 & 4.57 & التعليمى للطلبة. الأسرة بما يخدم نطوير المستوى \\
\hline عالِ جدًا & 0.87 & 4.41 & بتنائج أبنائهم التعليمية. المدرسة مع الأسرة؛ لتزويدهم \\
\hline عالِ جدًا & 0.81 & 4.38 & تحضور مديرة المدرسة الأسرة على المشاركة عبر الخاصنة \\
\hline
\end{tabular}




\begin{tabular}{|c|c|c|c|c|}
\hline \multirow[b]{2}{*}{ عالِ جدًا } & \multirow[b]{2}{*}{0.89} & & \multicolumn{2}{|l|}{ التربوية. } \\
\hline & & 4.25 & الأمبادل مديره التعدرسة النيمية النشورة مع الأسرة في & 4 \\
\hline عالِ جدًا & 0.86 & 4.22 & و التعاون مديرة المدرسة مع الأسرة؛ لتنفيذ الخطط التعليج & 5 \\
\hline عالِ جدًا & 0.92 & 4.20 & 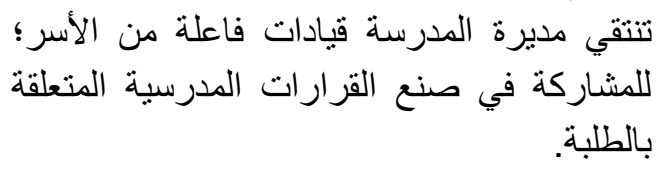 & 6 \\
\hline عالٍ & 0.93 & 4.18 & 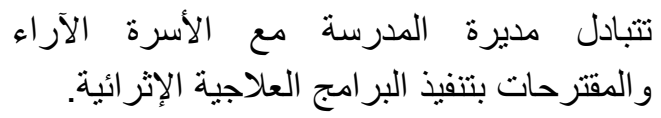 & 7 \\
\hline عالٍ & 0.93 & 4.15 & 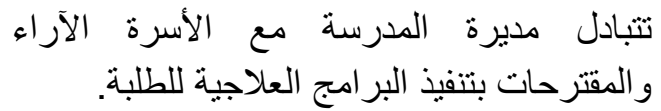 & 8 \\
\hline عالٍ & 1.11 & 4.05 & المتفرم مديرة المدرسة أسرة (ولي الأمر) الطلبة & 9 \\
\hline عالٍ & 1.01 & 3.92 & 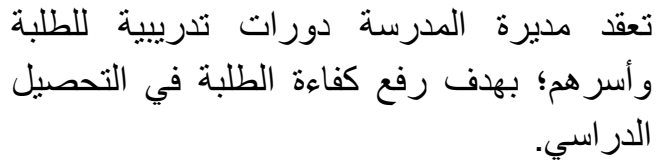 & 10 \\
\hline عالِ جدًا & 0.71 & 4.23 & اكة في المجال التعليمي & \\
\hline
\end{tabular}

أبرز الجدول 6 المنوسطات الحسابية لفقرات محور تفعيل الثراكة بين المدرسة والأسرة في المجال التعليمي تراوحت

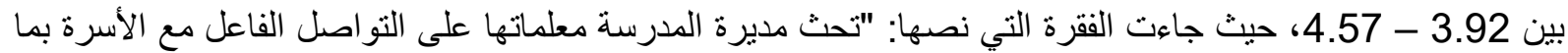

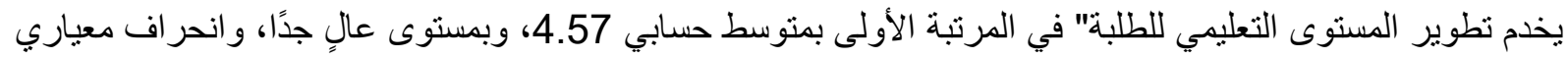
0.69، وجاءت في المرتبة الأخيرة الفقرة الني نصت على: "لتعقد مديرة المدرسة دورات تدريبية للطلبة وأسر هم؛ بهدف

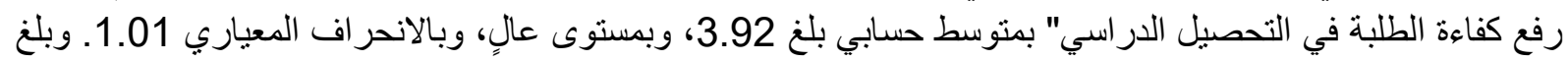
المتوسط الحسابي لمحور تفعيل الثر اكة في المجال التعليمي ككل 4.23، و وانحراف معياري درجة ممارسة مديرات مدارس الحلقة الأولى بمحافظة شمال الباطنة في سلطنة عمان في تفعيل الثر اكة بين المدرسة

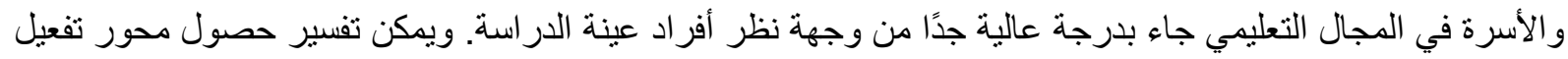

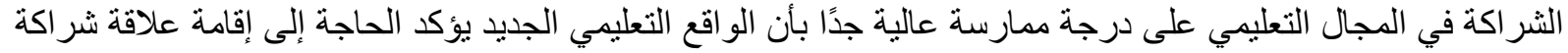

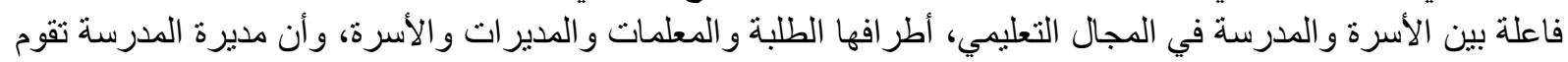

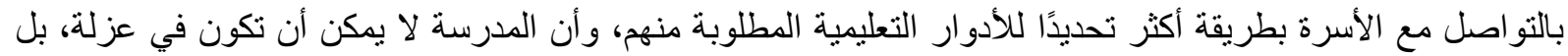

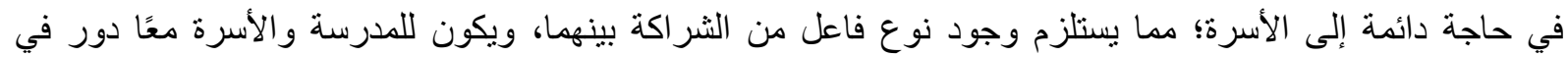

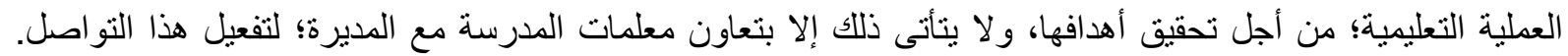

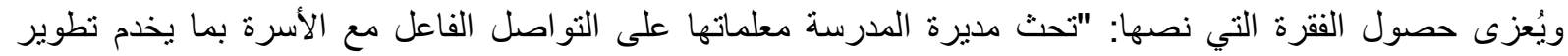

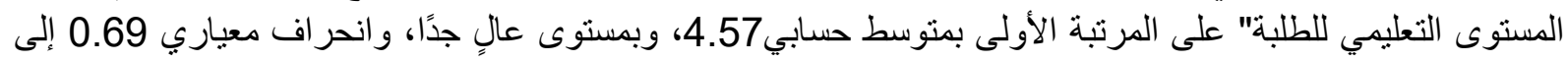

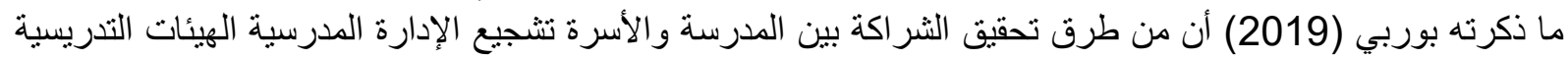

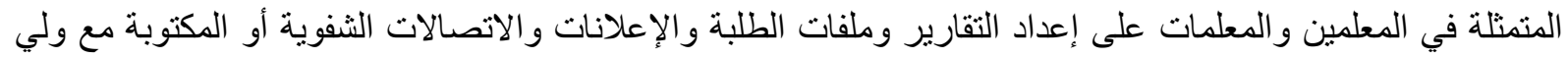

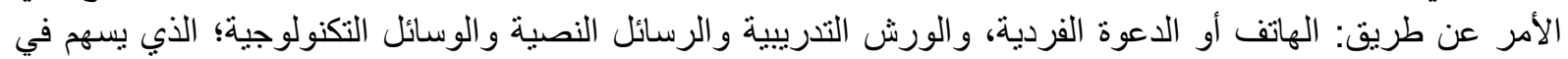

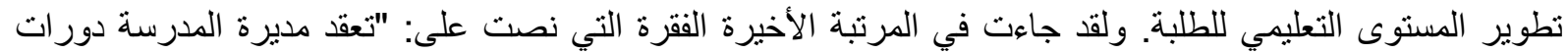

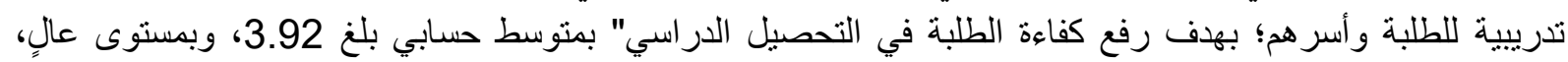
وبالانحر اف المعياري 1.01. ويمكن أن يُرد ذللك إلى وعي مديرات مدارس الحلقة الأولى بمدارس محافظة شمال الباطنة

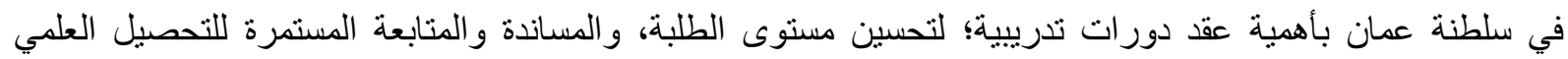


لأبنائهم، و إدراك مديرات المدارس وجود علاقة بين إقامة الدورات التدريبية للطلبة وأسرهم وتحسين مستوى الطلبة،

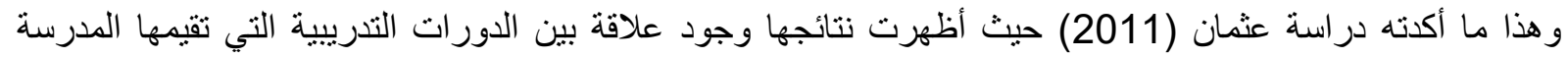

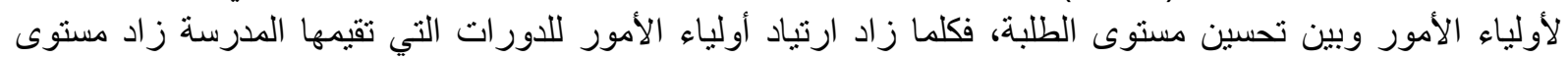
التحصيل الدر اسي لدى الطلبة.

\begin{tabular}{|c|c|c|c|c|}
\hline \multirow[b]{2}{*}{ 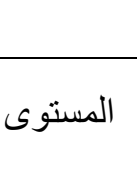 } & \multicolumn{4}{|c|}{ متوسطات الحسابية و الانحر افات المعيارية لفقرات محور تفعيل الثر اكة في المجال الاجتماعي } \\
\hline & الانحر اف المعياري & الحسابي & 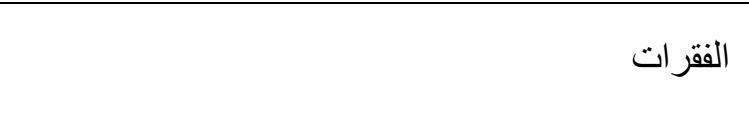 & الرتبة \\
\hline 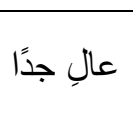 & 0.82 & 4.25 & 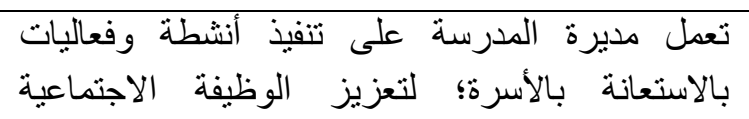 & 1 \\
\hline عالٍ & 0.98 & 4.02 & 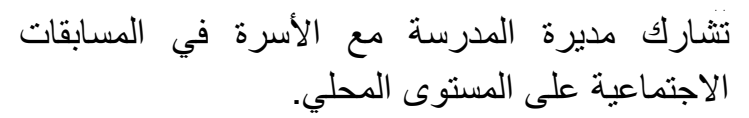 & 2 \\
\hline 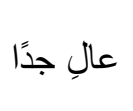 & 0.95 & 4.07 & تنظم مديرة المدرسة حملات توعوية تهدف إلى زيادة & 3 \\
\hline 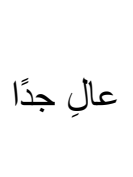 & 0.95 & 3.98 & 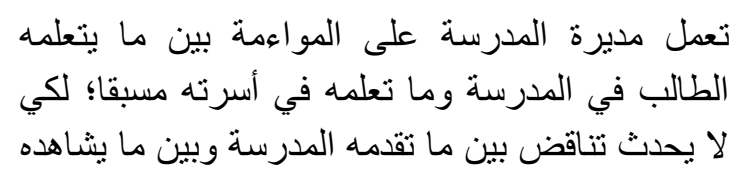 & 4 \\
\hline عالِ جدًا & 1.11 & 3.87 & 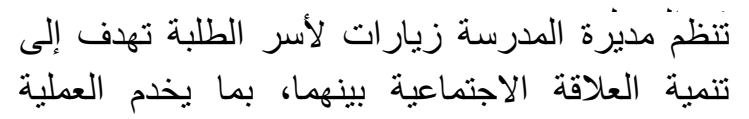 & 5 \\
\hline 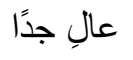 & 0.95 & 4.20 & تعقد مذيرة المدرسة اتفاقيات مع الأسرة؛ للارتقاء & 6 \\
\hline عالٍ & 0.90 & 4.23 & بعضارك المشاكل الاجتماعية للأسرة المدرسة فلقات نقاثنية؛ لحل & 7 \\
\hline عالِ جدًا & 0.87 & 4.12 & 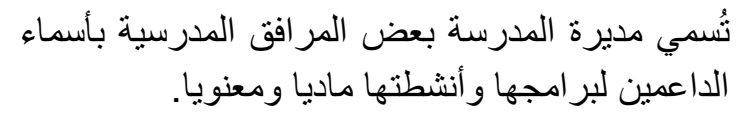 & 8 \\
\hline عالِ جدًا & 0.82 & 4.11 & تبنوم مديرة المدرسة برسم سياسة تربوية موحدة باتفاق الأسرة من حيث التعامل مع الابناء. & 9 \\
\hline عالٍ & 1.23 & 3.58 & تالقضايا المدرسية الاجتماعية. من خبر ات الأسرة في معالجة & 10 \\
\hline عالٍ & 0.78 & 4.04 & الشر اكة في المجال الاجتماعي ككل. & \\
\hline
\end{tabular}

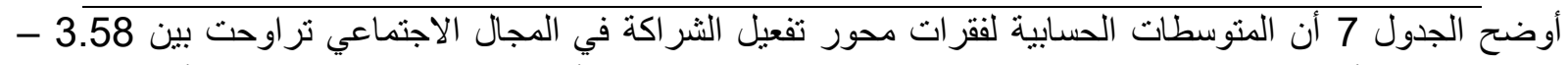

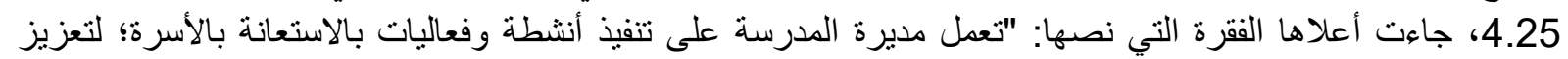

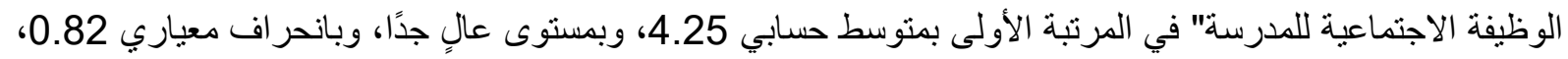

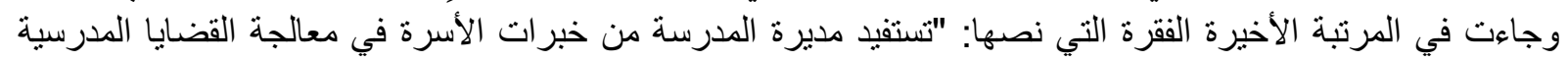

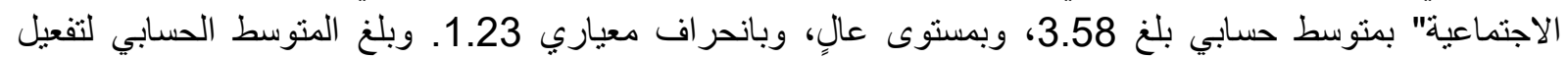

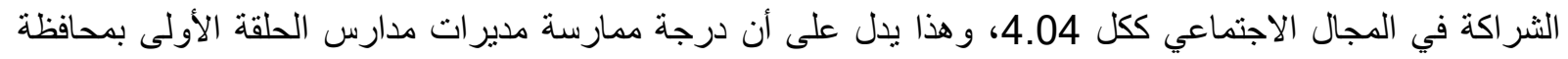

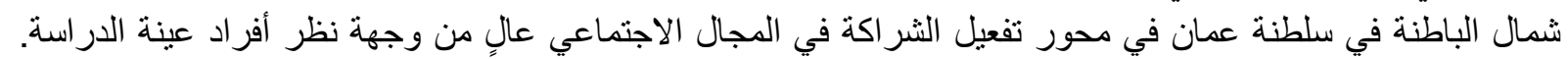

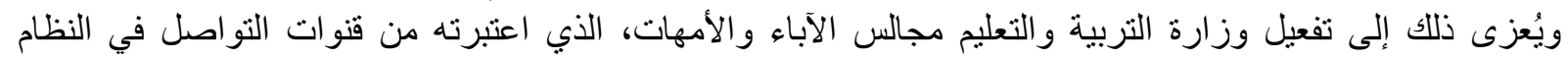

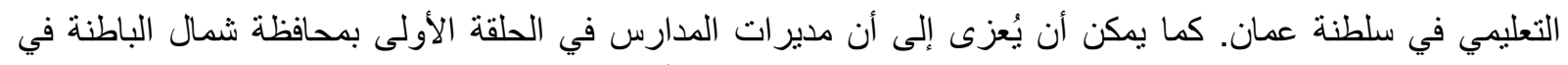

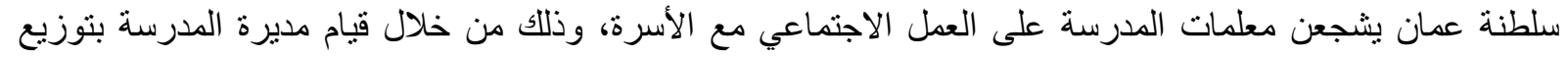


الأنشطة المدرسية على المعلمات، مثل: نشاط الرحلات، ونشاط الإذاعة المدرسية، ونشاط الصحة المدرسية، ونشاط

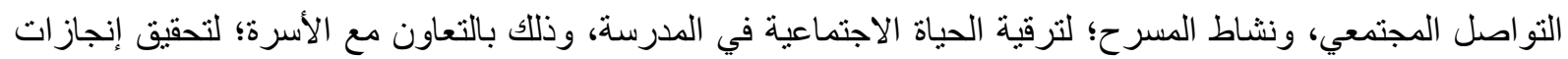

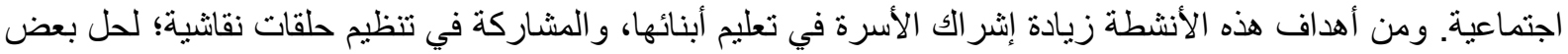

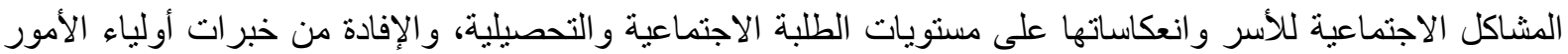

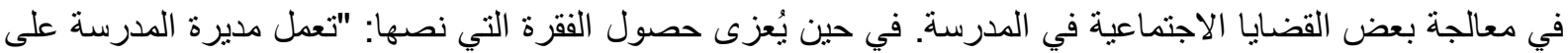

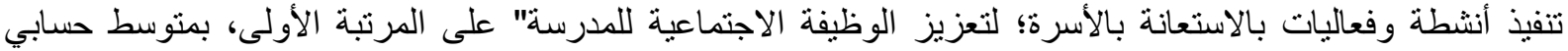

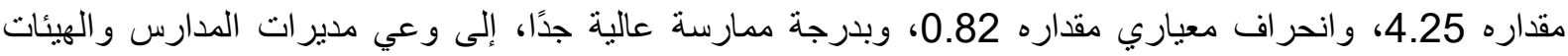

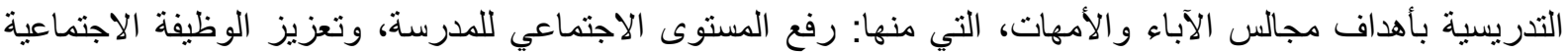

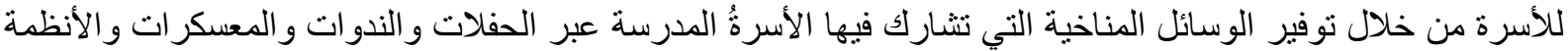

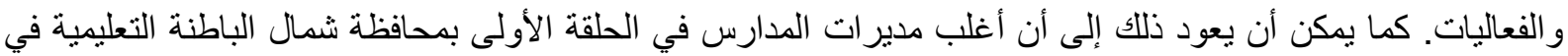

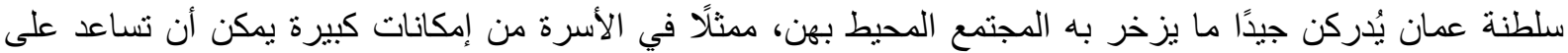

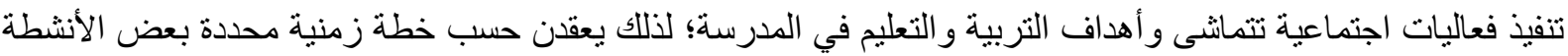

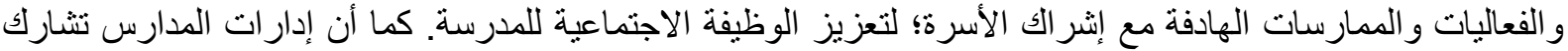

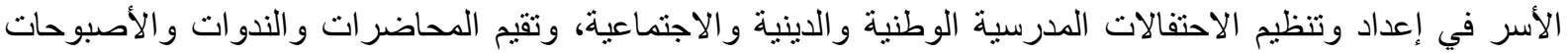

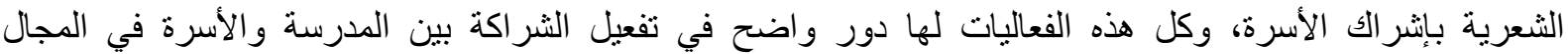

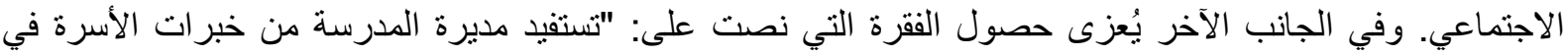

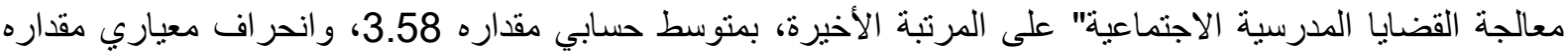
1.23، وبدرجة ممارسة عالية، إلى اعتبار الأسرة هي المدرسة الأولى التي ينشأ فيها الطالب، ودور ها الكا في وظيفة التكوين

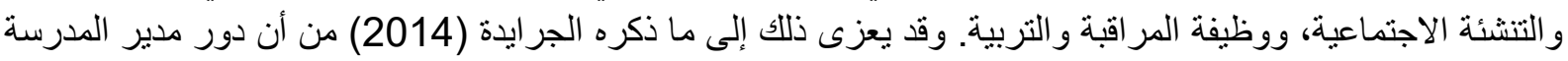

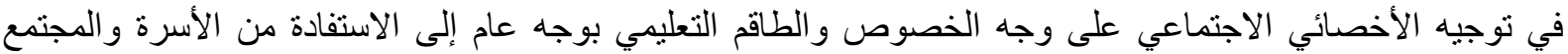

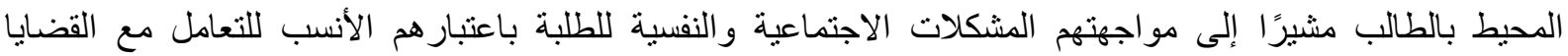

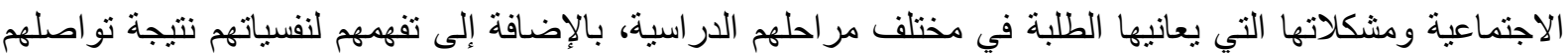

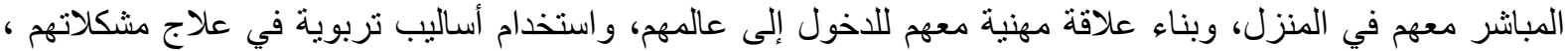

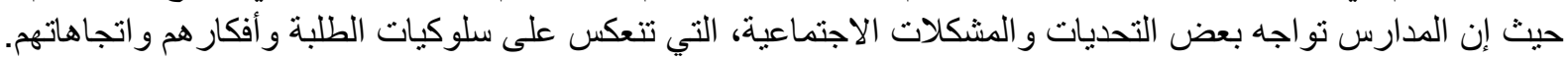

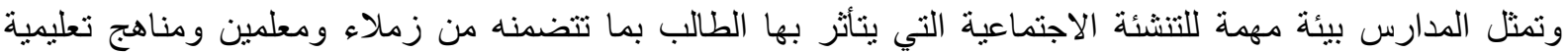
و أنشطة صفية وغير صفية. كما يساعد التنسيق وتفعيل الثراكة مع الأسرة على توظيف المجال الاجتماعي بصورة أفضل، من خلال تقوية الفعاليات الاجتماعية.

\section{النتائج المتعلقة بالسؤال الثاني ومناقشتها}

1. هل توجد فروق ذات دلالة إحصائية بين درجة ممارسة مديرات مدارس الحلقة الأولى بمحافظة شمال الباطنة في

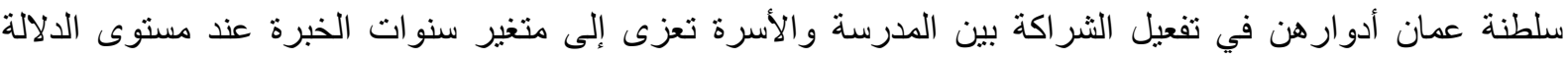

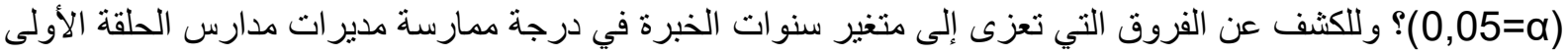

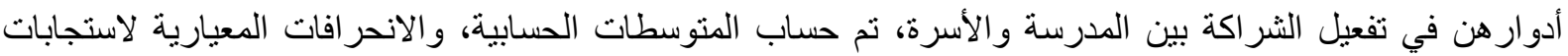

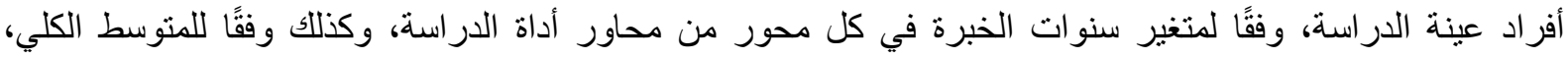
و الجدول رقم 8 يوضح هذه النتائج. جدول8 المتوسطات الحسايية والانحر افات المعيارية لدرجة ممارسة مديرات مدارس الحلقة الأولى في شمال الباطنة أدو ارهن في

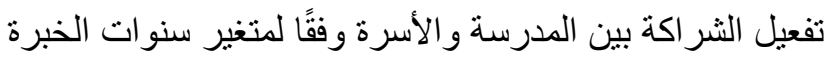

\begin{tabular}{|c|c|c|c|c|}
\hline المعياري & الحسابي & ن & سنوات الخبرة & المحاور \\
\hline 0.59 & 4.31 & 109 & 5 إلى أقل من 10 سنوات & تف 1 \\
\hline 0.71 & 4.22 & 66 & 10 إلى 15 سنة & \\
\hline
\end{tabular}




\begin{tabular}{|c|c|c|c|c|}
\hline 0.55 & 4.40 & 69 & أكثر من 15 سنة & \\
\hline 0.71 & 4.27 & 109 & 5 إلى أقل من 10 سنوات & \\
\hline 0.73 & 4.10 & 66 & 10 إلى 15 سنة & تفعيل الثر اكة في المجال التعليمي \\
\hline 0.68 & 4.30 & 69 & أكثر من 15 سنة & \\
\hline 0.79 & 4.06 & 109 & 5 إلى أقل من 10 سنوات & \\
\hline 0.84 & 3.92 & 66 & 10 إلى 15 سنة & تفعيل الثر اكة في المجال الاجتماعي \\
\hline 0.69 & 4.14 & 69 & أكثر من 15 سنة & \\
\hline 0.66 & 4.21 & 109 & 5 إلى أقل من 10 سنوات & \\
\hline 0.71 & 4.08 & 66 & 10 إلى 15 سنة & المتوسط الكلي \\
\hline 0.61 & 4.28 & 69 & أكثر من 15 سنة & \\
\hline
\end{tabular}

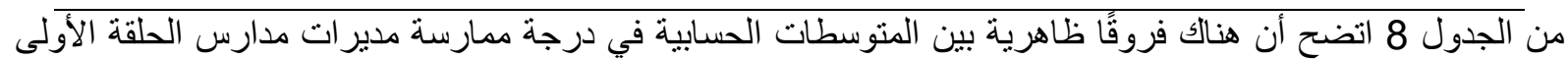

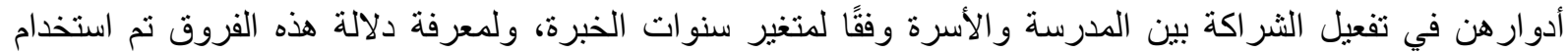

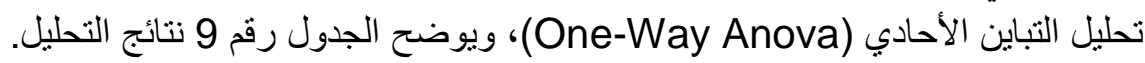
جدول9 نتائج تحليل التباين الأحادي للفروق في درجة ممارسة مديرات مدارس الحلقة الأولى في شمال الباطنة أدوارهن في

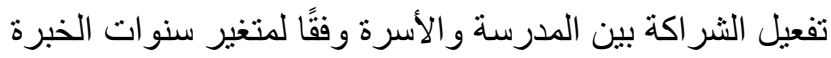

\begin{tabular}{|c|c|c|c|c|c|c|}
\hline الاحتمالية القيمة & $\mathrm{F}$ & منوسط & الحرية & مجموع المربعات & مصدر التباين & المتغير \\
\hline \multirow{3}{*}{0.249} & \multirow{3}{*}{$\begin{array}{r}1.4 \\
0\end{array}$} & 0.52 & 2 & 1.04 & بين المجمو عات & \multirow{3}{*}{ تقجيل الثراكة في الثقافي } \\
\hline & & 0.37 & 241 & 90.07 & داخل المجمو عات & \\
\hline & & & 243 & 91.11 & المجموع & \\
\hline \multirow{3}{*}{0.202} & \multirow{3}{*}{$\begin{array}{r}1.6 \\
1\end{array}$} & 0.81 & 2 & 1.61 & بين المجمو عات & \multirow{3}{*}{ تفعيل الثراكة في } \\
\hline & & 0.50 & 241 & 120.41 & داخل المجمو عات & \\
\hline & & & 243 & 122.02 & المجموع & \\
\hline \multirow{3}{*}{0.239} & \multirow{3}{*}{$\begin{array}{r}1.4 \\
4\end{array}$} & 0.87 & 2 & 1.74 & بين المجمو عات & \multirow{3}{*}{ تقعيل الثراكة في } \\
\hline & & 0.60 & 241 & 145.48 & داخل المجمو عات & \\
\hline & & & 243 & 147.22 & المجموع & \\
\hline \multirow{3}{*}{0.204} & \multirow{3}{*}{$\begin{array}{r}1.6 \\
0\end{array}$} & 0.70 & 2 & 1.41 & بين المجمو عات & \multirow{3}{*}{ الهتوسط الكلي } \\
\hline & & 0.44 & 241 & 105.94 & داخل المجمو عات & \\
\hline & & & 243 & 107.35 & المجموع & \\
\hline
\end{tabular}

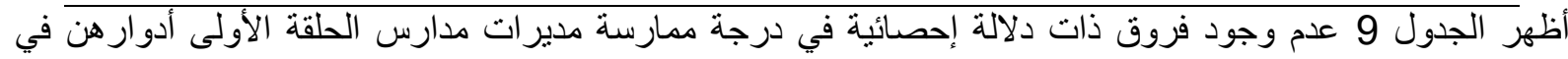

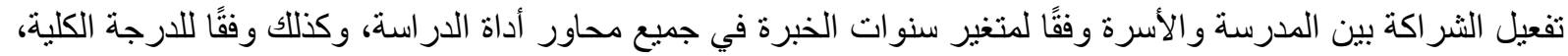

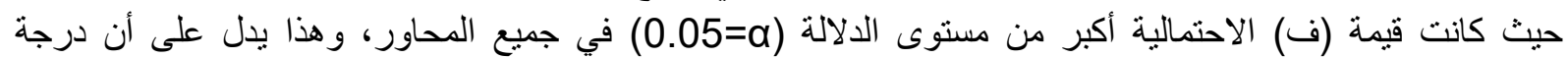

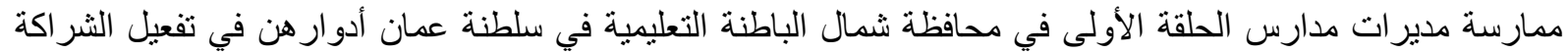

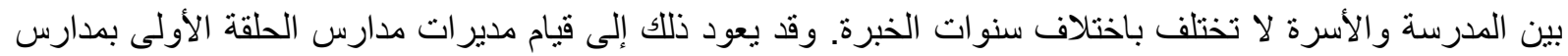

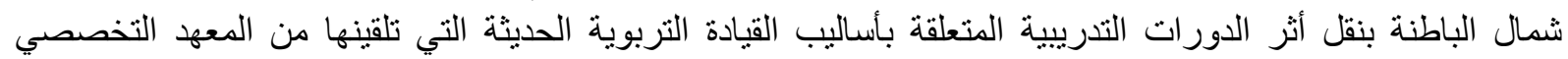

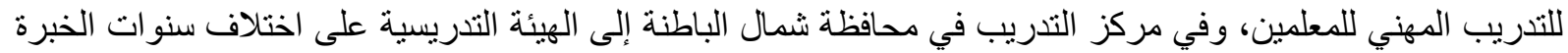


للمعلمات، وتنفيذ المهام و اللو ائح التي تقضي بإثر الك المعلمات على اختلاف سنو ات خبرتهن بتفعيل الثر اكة بين المدرسة

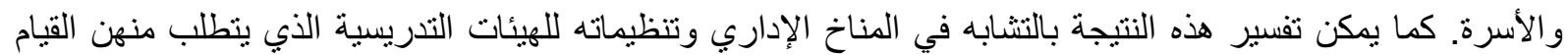

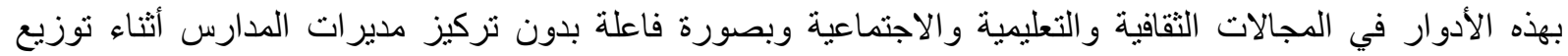

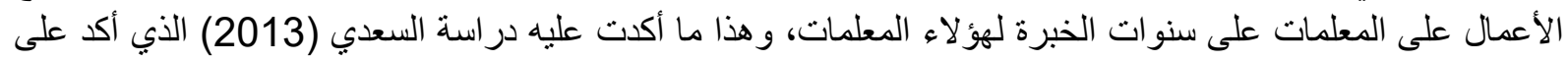

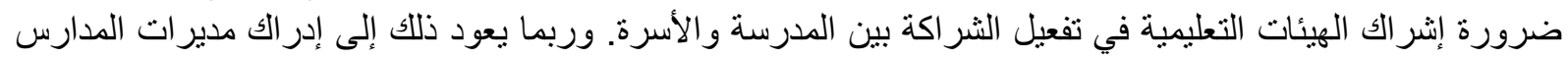

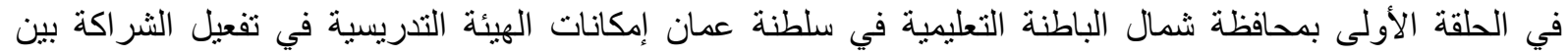

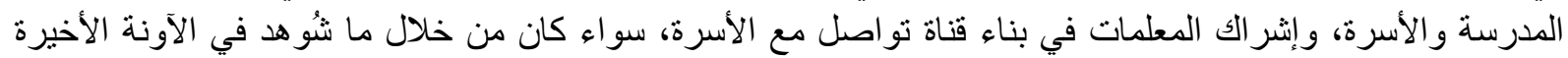

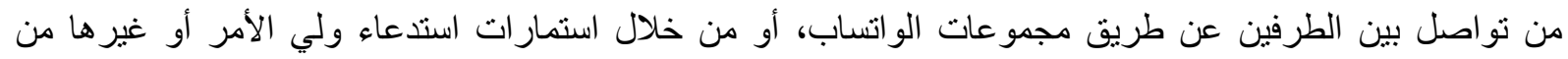

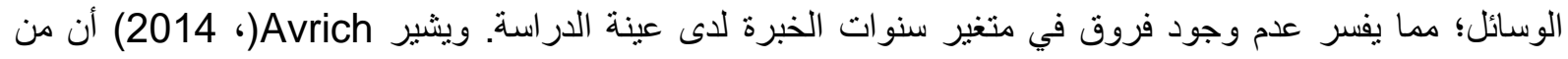

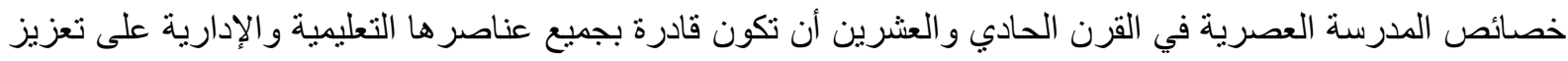

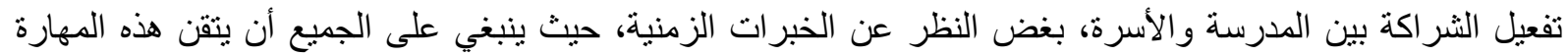

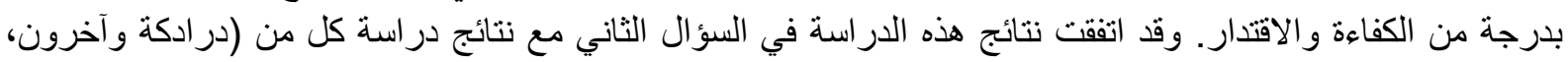

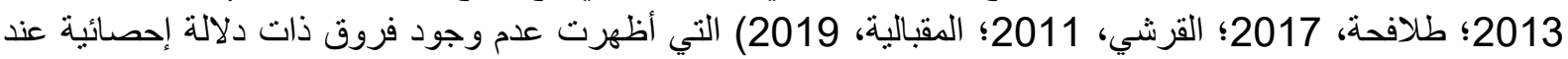

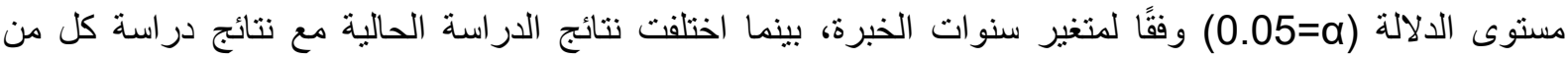

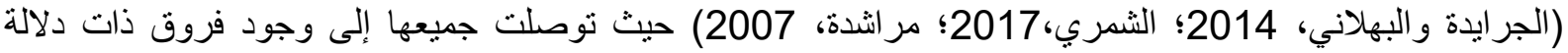

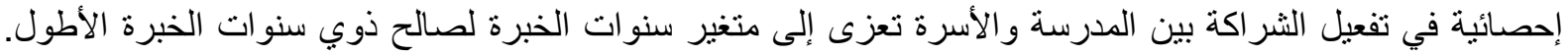

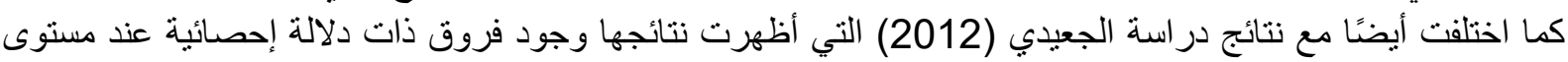
الدلالة (2011=a) (2011) حيث جاءت النتائج دالة على وجود فروق بين استجابات أفراد العينة تعزى إلى متغير سنوات اتل الخبرة من 10 - 15 سنة.

\section{التوصيات والمقترحات}

بناءً على النتائج التي توصلت إليها الدر اسة فيمكن التوصية بالآتي:

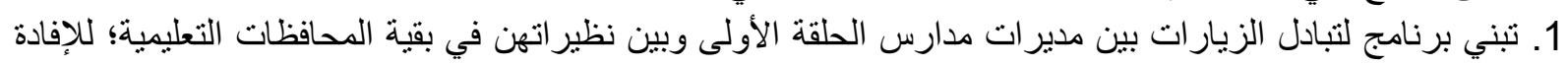

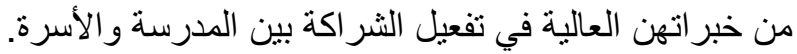

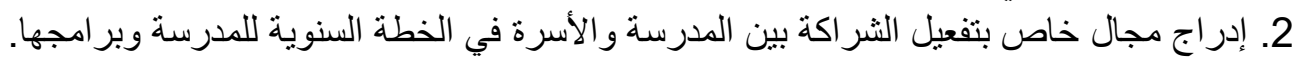

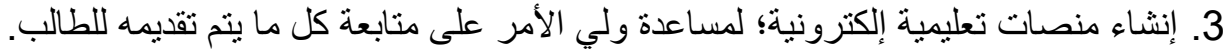

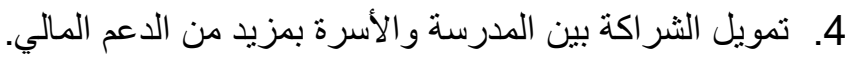

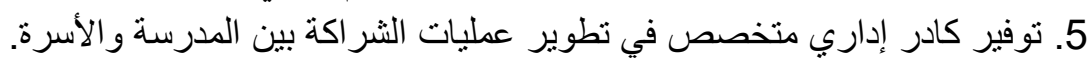
أما أبرز المقترحات فنتمثل في الآتي:

1. إجر اء در اسات مشابهة نطبق على الثى عينات أخرى (أخصائيات اجتماعيات، مساعدات مديرات، أولياء أمور)؛ لمعرفة

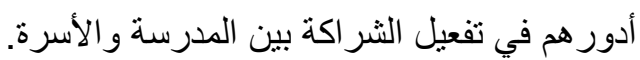
2. إجراء دراسات عن وضع فئ خطط مدروسة في كيفية تفعيل الثر اكة بين المدرسة والأسرة إلكترونيًا، وقياس فاعليتها على تعزيز الثر اكة بين المدرسة والأ دأسرة. 3. إجراء دراسة لبحث آراء المسؤولين بوزارة التربية والتهة التعليم ومقترحاتهم في أهم ما يمكن القيام به؛ لأجل تحسين العلاقة بين المدرسة و الأسرة.

\section{مراجع الدراسة ومصادرها}

إبراهيم، حسام الدين محمد. (2018). تصور مقترح لتفعيل الثراكة الأسرية في المدارس الابندائية المصرية في ضوء

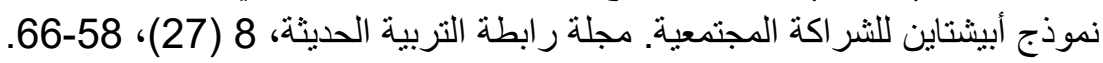

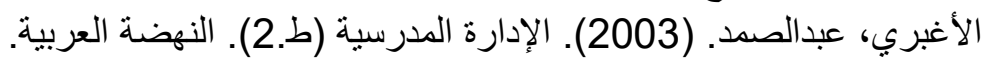

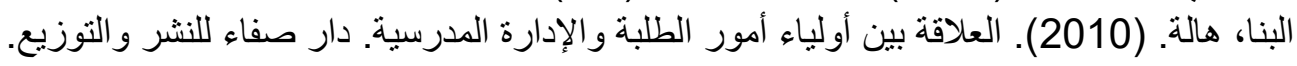


البندراوي، عيد. (2012). أثر الثر اكة بين وزارة التربية والتعليم و الجمعيات الأهلية في دعم العملية التعليمية في مصر

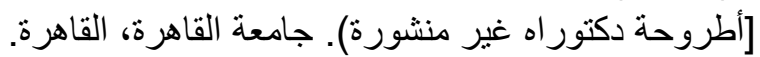

بوروبي، فريدة. (2019). دور الثراكة بين الأسرة والمدرسة لإرساء الثقافة عند التنلاميذ، مجلة العربي للاراسات

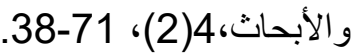

الجر ايدة، محمد. (2014). أنموذج مقترح لتقبيم الكفاءة التربوية للمدرسة في وزارة التربية والتعليم في سلطنة عمان.

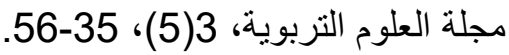

الجر ايدة، محمد سليمان، و البهلاني، ناصر حاربة، (5) (2014). أنموذج مقترح لتفعيل دور الثر اكة المجتمعية في المدارس

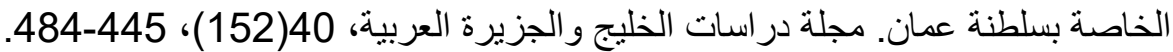

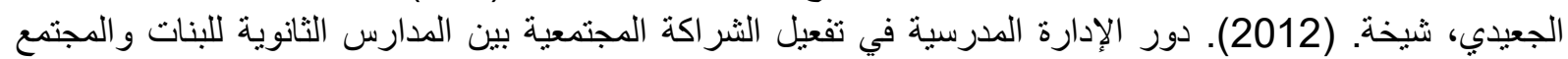

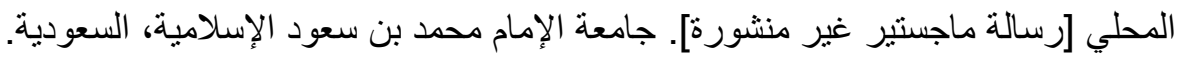

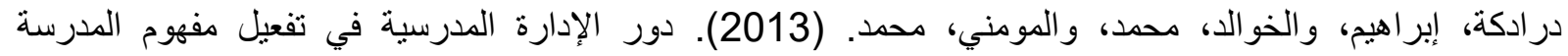

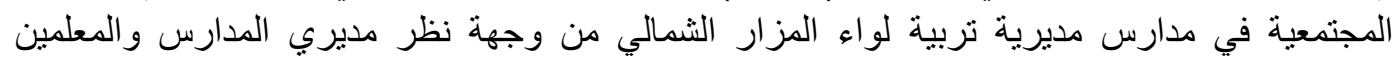

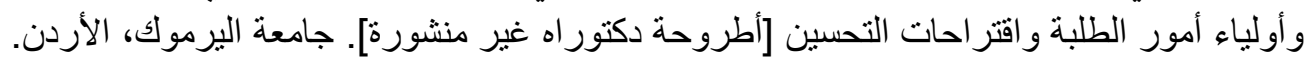

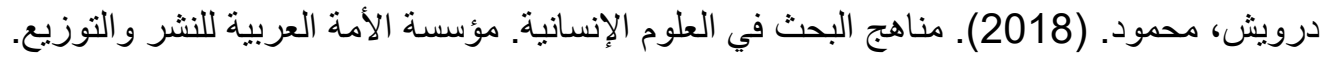

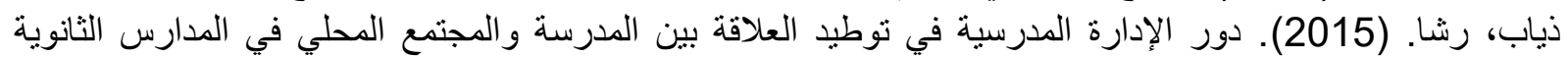

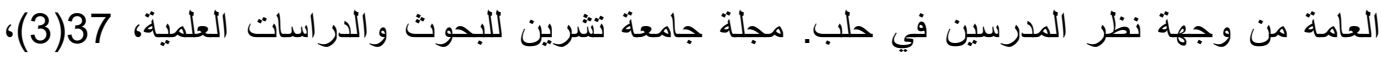

.374-373

السعدي، خالد بن محمد بن أحمد. (2013). تطوير أداء مجالس الآباء والأمهات في مدارس محافظة شمال الباطنة

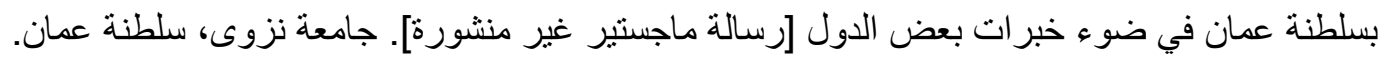

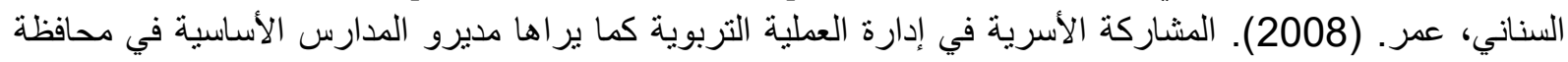

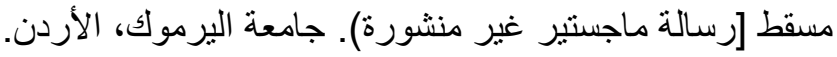

الثمري، خالد. (2017). مدى تفعيل الإدارة الددرسية للشر اكة بين المدرسة و المجتمع الئرة المحلي: المعيقات وسبل التحسين.

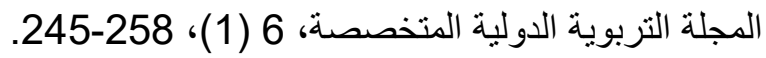

الصرايرة، بشرى نواف. (2019). التمكين والذمة المالية المستقلة للمر أة العاملة وعلاقتهما في العنف الأسري. دار الخليج للنشر و التوزيع.

الصوافية، نصراء. (2008). تفعيل الثراكة المجتمعية بين المدرسة والمجتمع المحلي في بعض الجوانب الإدارية

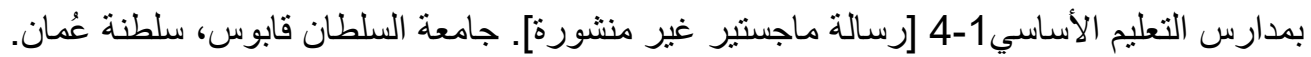

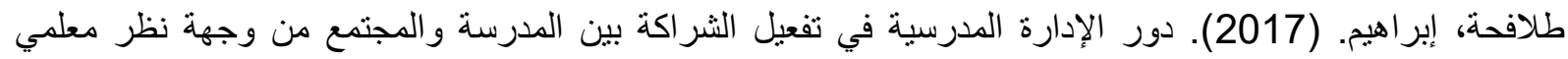

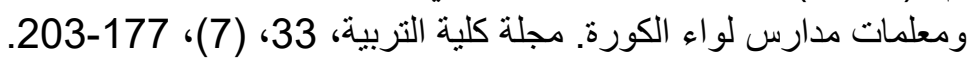

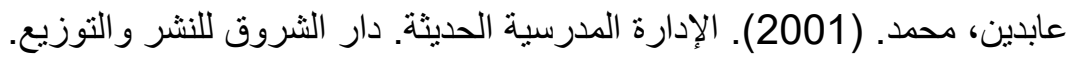

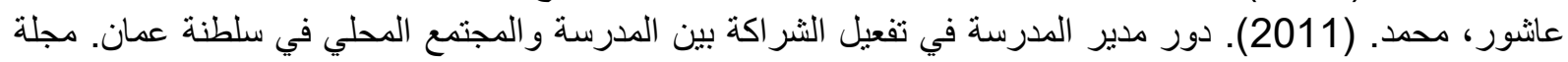

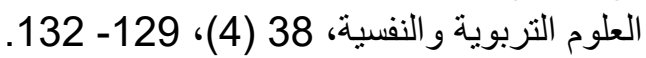

عاشور، محمد. (2010). دور مدير المدرسة في تفعيل الثر اكة بين المدرسة والمجنة النمع المحلي في سلطنة عمان. مجلة

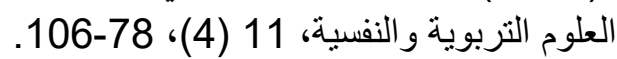

عثمان، ستنا. (2011). علاقة المستوى الاجتماعي والثقافي بتحصيل طلبة مرحلة التعليم الأساسي في السودان. مجلة

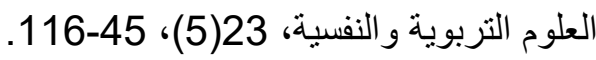

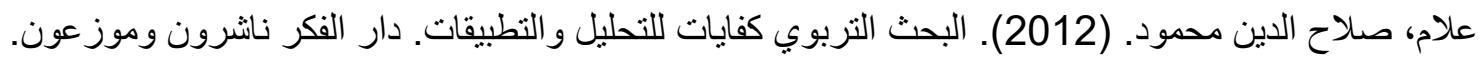

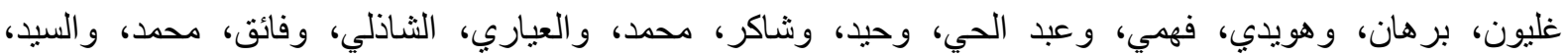

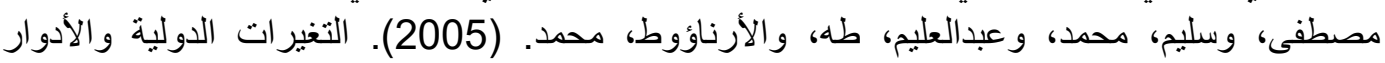

$$
\text { الإقليمية الجديدة. المؤسسة العربية للادر اسات و والنشر. }
$$

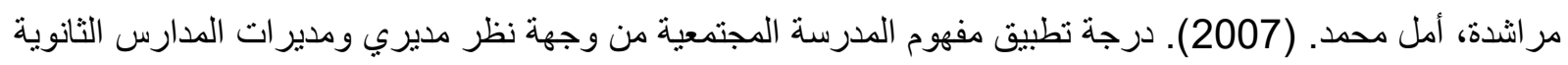

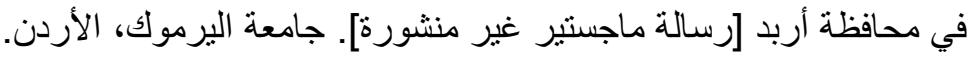

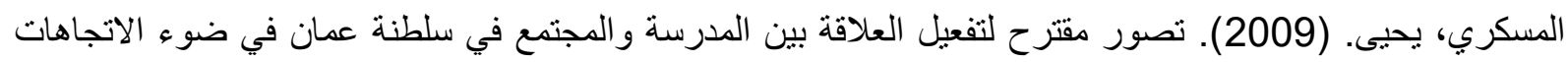

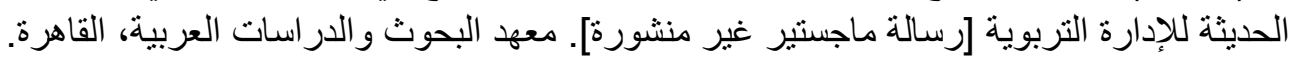


المسهلي، مسلم .(2012). دور مجالس الآباء والأمهات في تحسين جودة التعليم. ورقة علمية مقدمة إلى ندوة مجتمع ظفار التربوي بجامعة ظفار، ظفار ، سلطنة عمان.

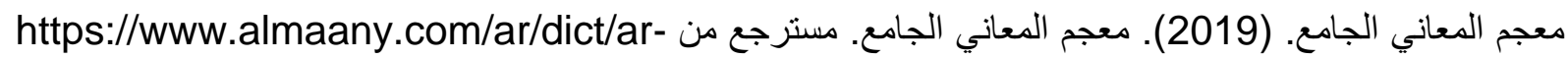
ar

المقبالية، عائشة. (2019). دور الإدارة المدرسية في تفعيل الثراكة المجتمعية [رسالة ماجستير غير منشورة]. جامعة صُحار، سلطنة عمان.

المنوفي، محمد إبر اهيم، و هلال، عصام الدين علي، والثمري، وليد موسى سالم. (2020). متطلبات تعزيز الشر اكة بين

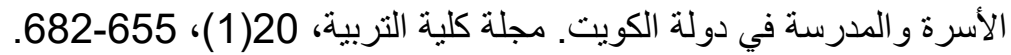

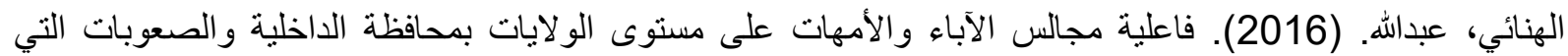

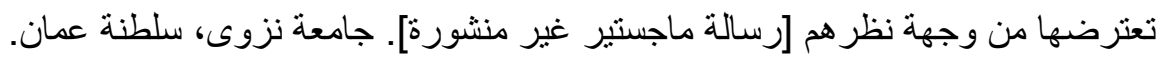

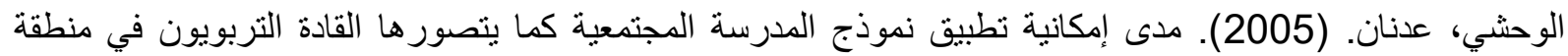

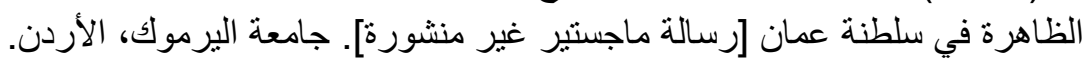

وزارة التربية و التعليم. (2006). الثر اكة المجتمعية بين المدرسة وأولياء الأمور. مجلة التطوير التربوبة اليردي، سلطنة عمان: مسقط.

وزارة التربية و التعليم، (2002). لائحة مجلس الآباء والأمهات. مسقط. سلطنة عمان. مسترجع من: http://moe.gov.om/Portal/sitebuilder/Sites/EPS/Arabic/MOE/EduLows/Gen .eralSch/loworg.aspx وزارة التربية والتعليم، (2008). دليل نظام تطوير الأداء المدرسي. التخطيط التربوي وتتمية الموارد البشرية.

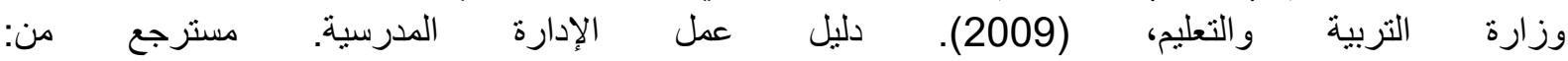 .https://home.moe.gov.om/library/15/show/177

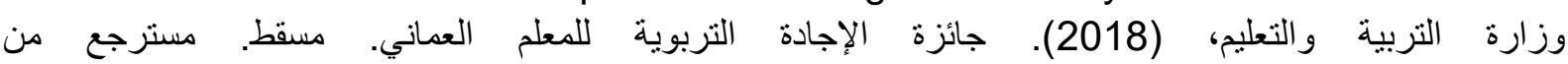
https://ota.moe.gov.om

وزارة التربية والتعليه، (2019). التقرير السنوي للتعليم في سلطنة عمان. مسقط، سلطنة عمان.

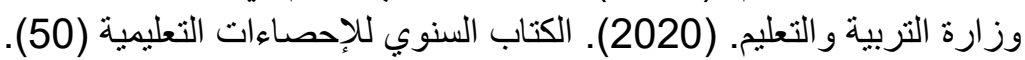
يحياوي، نجاة. (2018). علاقة الأسرة بالمدرسة في العملية التعليمية. دفاتر مخبر المسألة التربوية في ظل التحدية التحديات الراهنة، (20)، (2018-5 (14).

Avrich, P. (2014). The Modern School Movement: Anarchism and Education in the United States. Princeton University Press.

Bryan, J. \& Henry, L. (2012). A Model for Building School-Family- Community Partnerships: Principles and Process. Journal of Counseling and Development, 90 (4), 408-420.

Dietz M. (1997). School, family, and community: Techniques and models for successful collaboration. Gaithersburg, Maryland: Aspen.

George, D. \& Mallery, M. (2010). SPSS for Windows Step by Step: A Simple Guide and Reference (10 Ed.). Boston: Pearson.

Griffith, J. (2001). Principal leadership of parent involvement. Journal of Educational Administration.39 (2), 162-180.

Happy, F. (2008). Bights and Rower as new dynamics in the American school system. Bulletin, 64 (432), 20-35.

Manasse, A. (2003). Principals as leaders of high performing systems. Educational Leader, 41(5), 42-46.

Martin, L. (2005). School Partnerships: A Guide for Parents, Schools, and Communities. Manitoba: The Minister of Education, Citizenship and 
Teenagers. Manitoba Education, Citizenship and Teenagers, School Programs Division.

Mutch, C. \& Collins, S. (2012). Partners in Learning Schools Engagement with parents, Families and communities in New Zealand. School community journal, 22 (1), 167-170.

Peterson, R. (2006). Planning procedures and leadership role of the principal in professional development school (Unpublished doctoral dissertation). Ball State University.

Turner, H. (2006). Handbook of Sociological Theory. Springer Science Business Media. 